Stability and Overtopping Study of Montrose to Irving Reach of Chicago, IL, Shoreline Revetment

Elizabeth C. Burg and Jeffrey A. Melby

February 2008 


\title{
Stability and Overtopping Study of Montrose to Irving Reach of Chicago, IL, Shoreline Revetment
}

\author{
Elizabeth C. Burg and Jeffrey A. Melby \\ Coastal and Hydraulics Laboratory \\ U.S. Army Engineer Research and Development Center \\ 3909 Halls Ferry Road \\ Vicksburg, MS 39180-6199
}

Final report

Approved for public release; distribution is unlimited.

Prepared for Headquarters, U.S. Army Corps of Engineers

Washington, DC 20314 


\begin{abstract}
The stepped stone revetment along the City of Chicago's Lake Michigan shoreline, directly south of Montrose Harbor, is failing and in need of repair. The Illinois Historical Preservation Agency (IHPA) requested that the cut limestone blocks from the original structure be evaluated for use in the new revetment design. A physical model study was conducted at the U.S. Army Engineer Research and Development Center's Coastal and Hydraulics Laboratory to assist in the design of the composite structure. During the experiments, overtopping rates were measured and stone stability was noted. Construction-related issues, overtopping, and the sizing and stability of cut limestone blocks were of major interest during the study.
\end{abstract}

DISCLAIMER: The contents of this report are not to be used for advertising, publication, or promotional purposes. Citation of trade names does not constitute an official endorsement or approval of the use of such commercial products. All product names and trademarks cited are the property of their respective owners. The findings of this report are not to be construed as an official Department of the Army position unless so designated by other authorized documents. 


\section{Contents}

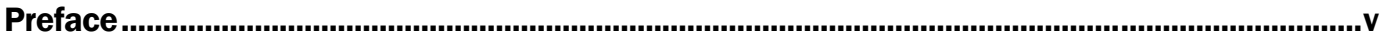

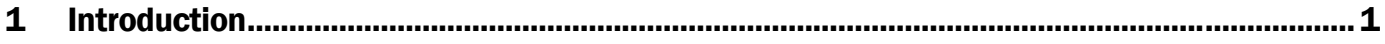

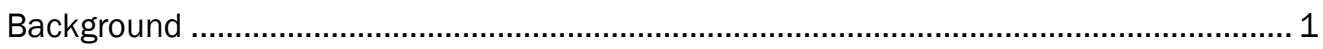

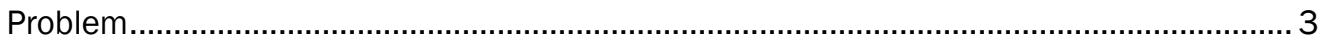

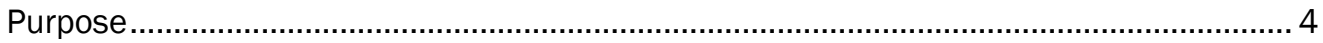

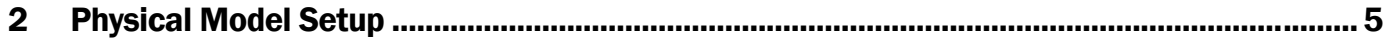

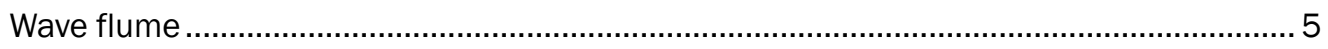

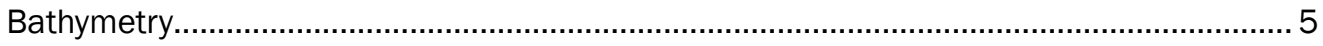

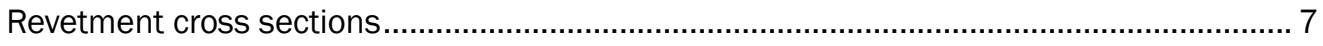

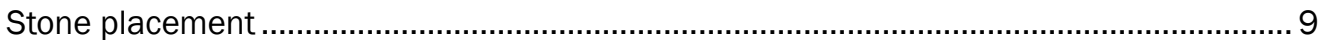

Storm waves and water levels .................................................................................... 11

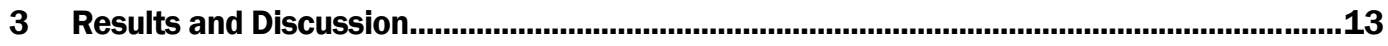

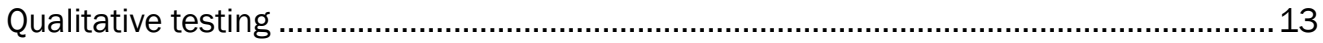

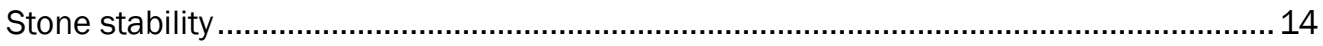

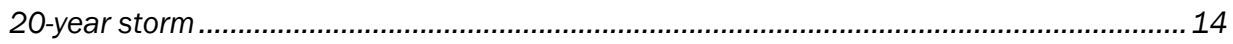

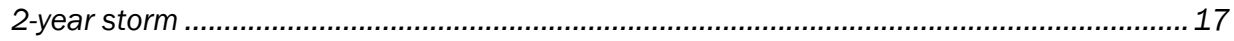

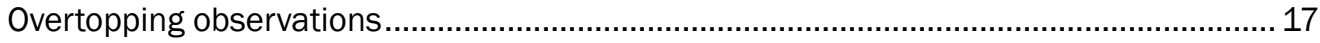

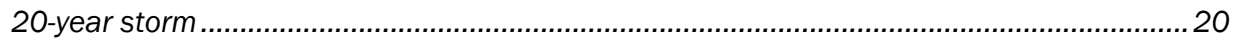

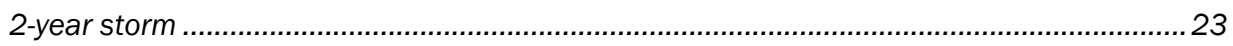

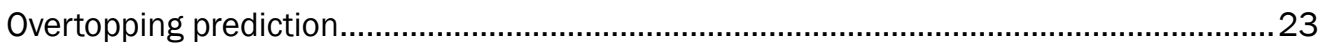

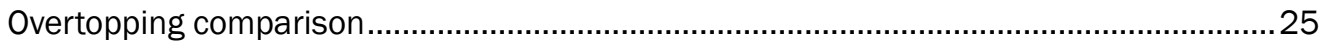

4 Conclusions and Recommendations ................................................................................28

References..............................................................................................................................................29

\section{Report Documentation Page}




\section{Figures and Tables}

\section{Figures}

Figure 1. Project limits for Chicago Shoreline Storm Damage Reduction Project................................ 1

Figure 2. Physical model study limits, Montrose to Irving Reach. ........................................................ 2

Figure 3. Typical cross section of current revetment design............................................................. 2

Figure 4. Example of revetment failure along Montrose to Irving reach................................................ 3

Figure 5. Cross section of wave flume

Figure 6. Bathymetry for Montrose to Irving Sections 1-4............................................................. 7

Figure 7. Direct overhead view of two-stone row cross section......................................................... 9

Figure 8. Three-stone row cross section as built in the flume. ........................................................... 10

Figure 9. Two-stone row cross section as built in the flume........................................................... 10

Figure 10. Stone placement for two-stone row design. ................................................................. 11

Figure 11. Stone placement for three-stone row design. ............................................................... 11

Figure 12. Side photographs from before and after the 20-year storm event................................ 15

Figure 13. Overhead photographs from before and after the 20-year storm event. ........................ 16

Figure 14. Overhead photographs from before and after the 20-year storm event zoomed

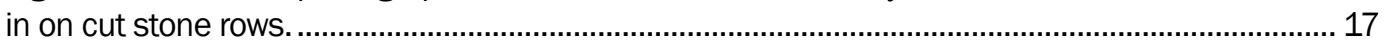

Figure 15. Side photographs from before and after the 2-year storm event.................................. 18

Figure 16. Overhead photographs from before and after the 2-year storm event.......................... 19

Figure 17. Overhead photographs from before and after the 2-year storm event zoomed in

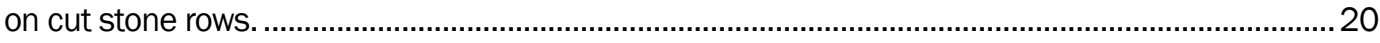

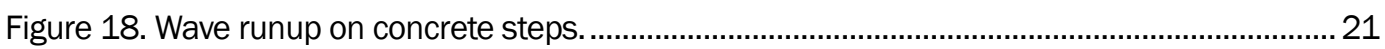

Figure 19. Wave overtopping three-stone row structure. ................................................................. 21

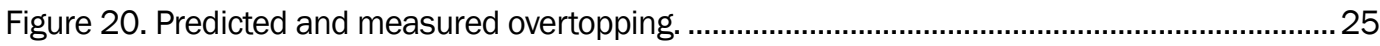

Figure 21. Comparison of results from Equation 1, measured overtopping recorded during testing, and Ward's equation for revetment geometry during 20-year storm event.......................... 26

Figure 22. Comparison of results from Equation 1, measured overtopping recorded during testing, and Ward's equation for revetment geometry during 2-year storm event.

\section{Tables}

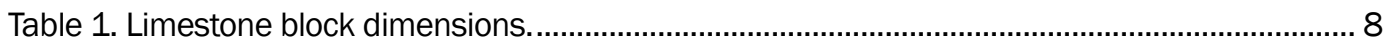

Table 2. Storm waves and water levels. ................................................................................... 12

Table 3. Wave properties and overtopping rates for 20-year storm................................................ 22

Table 4. Wave properties and overtopping rates for 2-year storm. ................................................. 24

Table 5. Geometric parameters for revetment cross section used for calculation in Ward's equation with elevations referred to Lake Michigan LWD.............................................................. 27 


\section{Preface}

This study was authorized by U.S. Army Engineer District (USAED), Chicago, and was conducted by personnel of the U.S. Army Engineer Research and Development Center's (ERDC) Coastal and Hydraulics Laboratory (CHL). The project was conducted during October 2006 to May 2007. The point of contact for the study was Drew Benziger, USAED, Chicago.

The physical model study was conducted by personnel of the Harbors, Entrances, and Structures Branch (HN-H) of the Navigation Division (HN), under the direction of Thomas Richardson and Dr. William Martin, Director and Deputy Director, CHL, respectively; Dr. Rose Kress, Chief, HN; and Jose E. Sanchez, Chief, HN-H. Glenn Myrick, Physical Scientist, HN-HR; William Henderson, Engineering Technician, HN-HR; Elizabeth Burg, Research Hydraulic Engineer, HN-HI; and Dr. Jeffrey Melby, Research Hydraulic Engineer, HN-HS, constructed the models used in the study and conducted the experiments in the wave flume. Burg and Dr. Melby analyzed the data and prepared this report.

COL Richard B. Jenkins was Commander and Executive Director of ERDC. Dr. James R. Houston was Director. 


\section{Introduction}

\section{Background}

The purpose of the Chicago Shoreline Storm Damage Reduction Project is to provide storm damage protection along the Lake Michigan shoreline. The authorized project includes the Chicago shoreline between Montrose Avenue and $56^{\text {th }}$ Street (Figure 1). Of particular concern is the protection of Lake Shore Drive, which is a Federal highway and a major thoroughfare in the city of Chicago. This study focuses on a small section of shoreline known as the Montrose to Irving reach, which extends south from Montrose Harbor approximately $610 \mathrm{~m}$ (2,000 ft) (Figure 2).

The existing structure along the shoreline from Montrose to Irving was built as part of an extensive lake-fill project during the 1920 s and 1930 . The shoreline was protected by a Wakefield sheeting and timber pile bulkhead, capped with cut Bedford limestone steps. Figure 3 illustrates the "as-built" typical cross section of the current revetment. The limestone steps hold aesthetic value in the community, are a popular relaxation spot, and also feature local art.

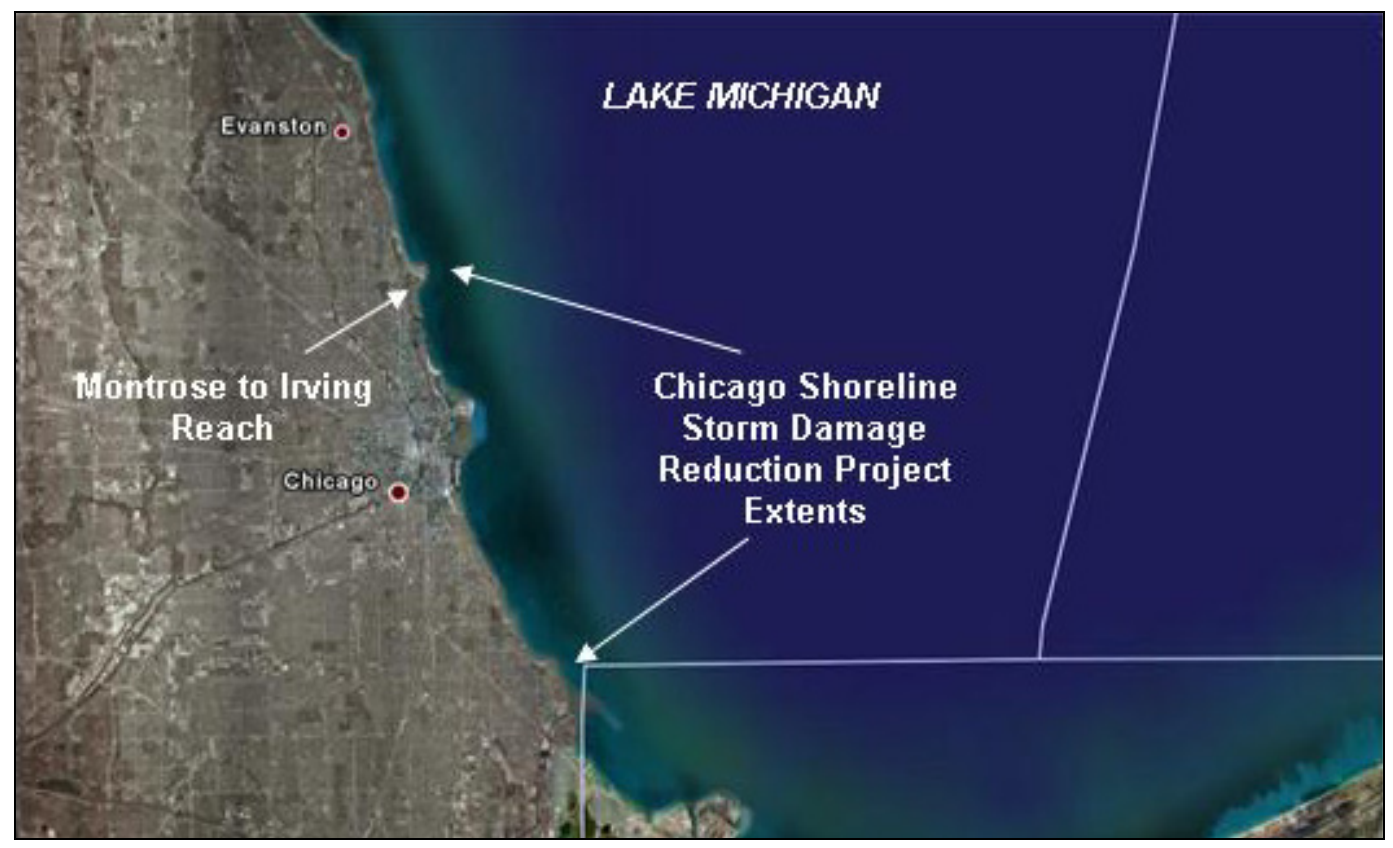

Figure 1. Project limits for Chicago Shoreline Storm Damage Reduction Project. 


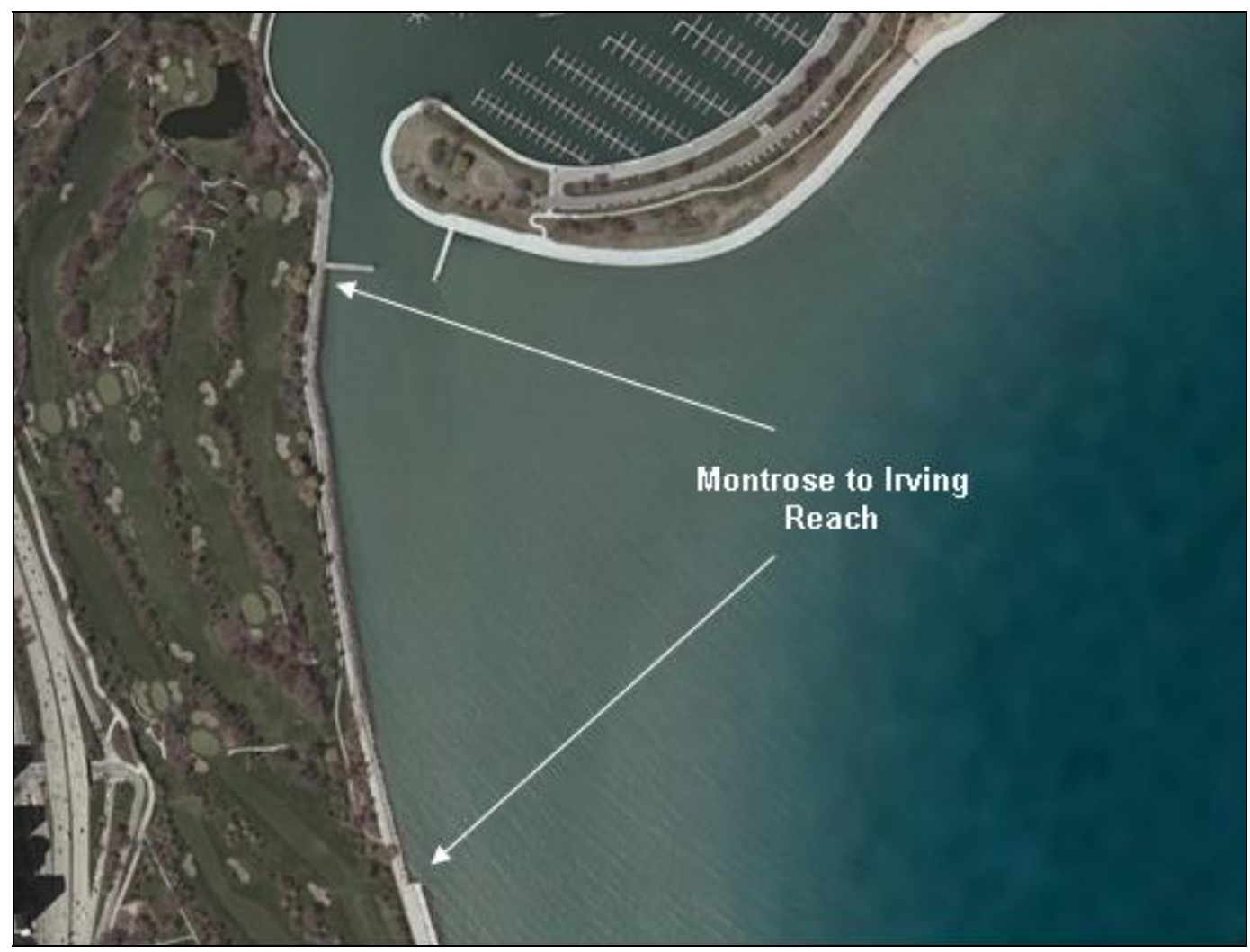

Figure 2. Physical model study limits, Montrose to Irving Reach.

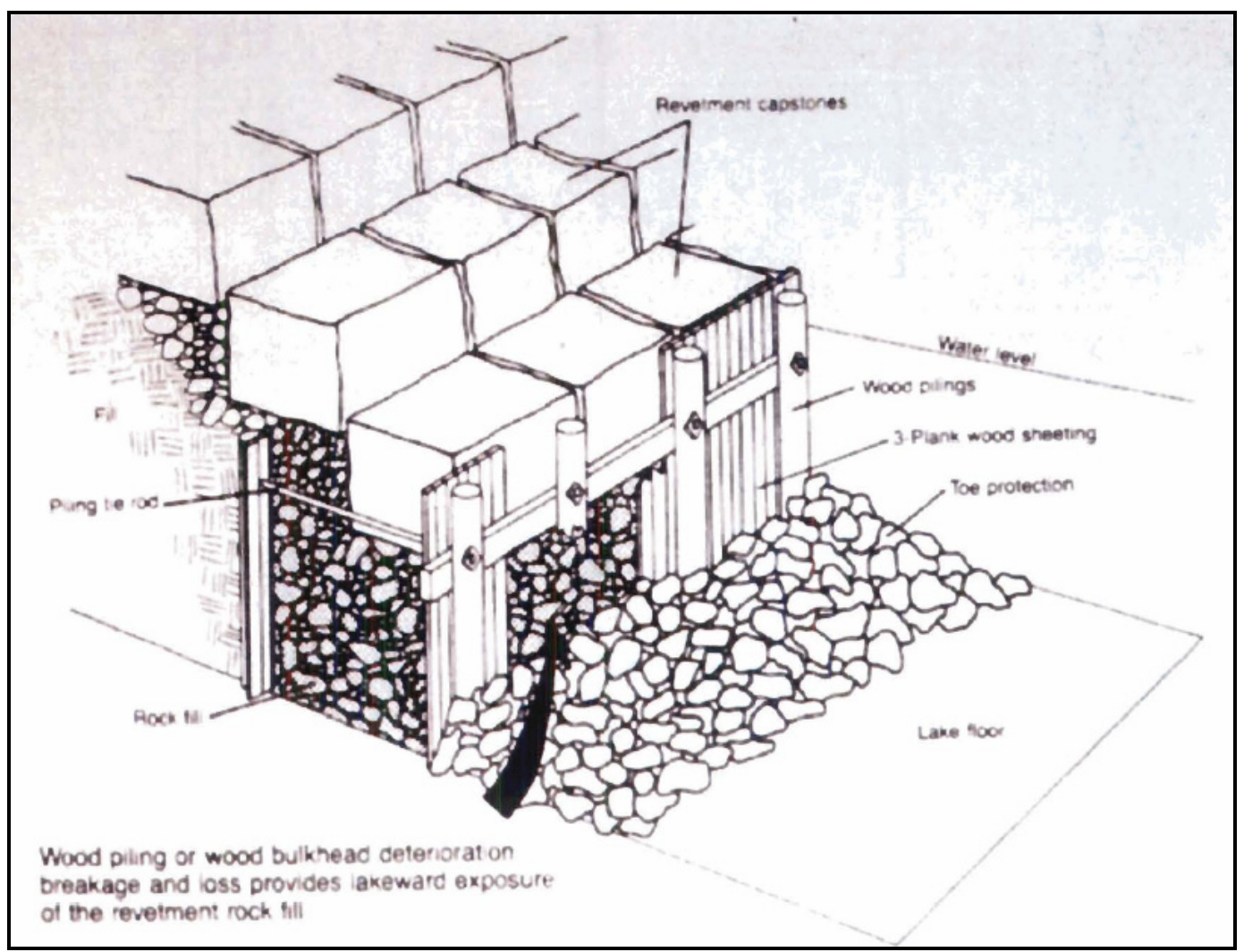

Figure 3. Typical cross section of current revetment design. 
Water levels in Lake Michigan have fluctuated significantly since the initial construction of the revetment and, in the process, exposed portions of the wood pilings that were previously submerged. The exposed timber piles have deteriorated and, in some locations along the shoreline, failed (Figure 4). The cut limestone blocks, which are fixed in place by concrete mortar, have started to collapse into voids left by backfill erosion. Several attempts have been made to repair the structure, including the addition of grout and concrete overlays, and the installation of steel piles and armor stone to buttress the revetment. Currently, the revetment along the Montrose to Irving reach is in need of reconstruction.

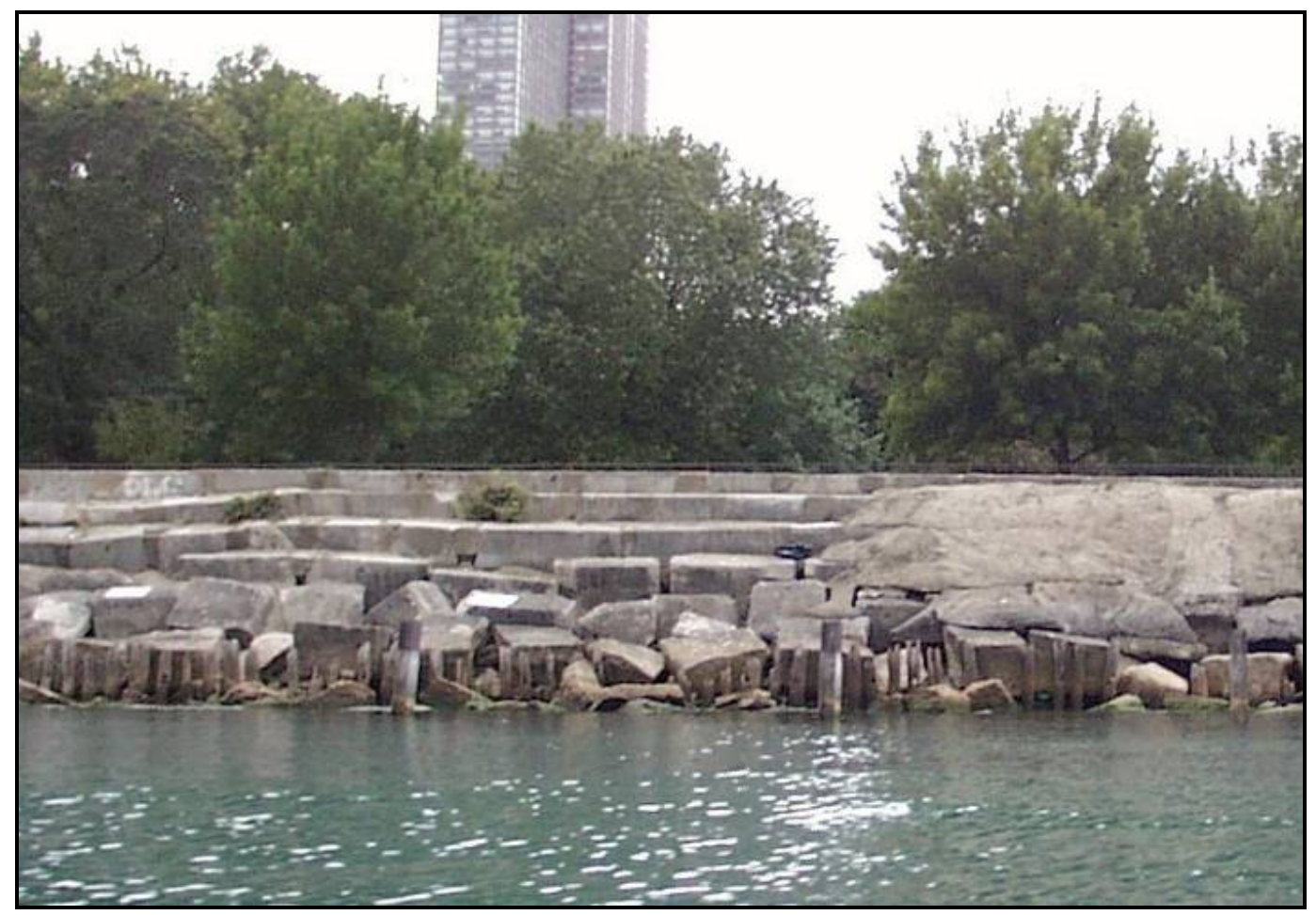

Figure 4. Example of revetment failure along Montrose to Irving reach (photograph courtesy of U.S. Army Engineer District, Chicago).

\section{Problem}

The Illinois Historical Preservation Agency (IHPA), whose approval of the project is a requirement under the NEPA process, has requested that the existing quarry stone be used in the redesign of the revetment. One possible design configuration consists of a steel sheet pile wall and a concrete promenade with two to three concrete steps leading up to two or three rows of the existing cut limestone placed in a step-stone fashion. It has been proposed to place the blocks loosely on the structure without grouting them together. This type of composite structure is not currently 
in use along the shoreline in locations subject to direct wave attack, and the constructability of such a structure is unknown. Two previous studies for stepped revetments along the Chicago shoreline outlined methods for estimating overtopping rates, but neither accounted for a composite structure and neither was specifically intended for the Montrose to Irving reach (Ward 2003, Krecic and Sayao 2003). The long-term stability of the cut limestone blocks as well as the appropriate size of armor stones is uncertain. Leaching of foundation material and overtopping rates for the range of proposed crest elevations are also in question. A physical model study was required to measure overtopping rates, observe stone and underlayer stability, and give recommendations for armor stone sizes for a proposed cross section.

\section{Purpose}

The purpose of this study was to determine the overtopping rates and observe stone and underlayer stability for one section of the Montrose to Irving reach, which will assist the U.S. Army Engineer District, Chicago (hereafter, Chicago District) in determining an effective revetment design for the Montrose to Irving reach. This study will also provide guidance to the Chicago District for sizing armor stones along the crest of the revetment as well as for identifying potential constructability issues. 


\section{Physical Model Setup}

\section{Wave flume}

The physical model study was conducted at the U.S. Army Engineer Research and Development Center's Coastal and Hydraulics Laboratory (CHL) in Vicksburg, MS.

All tests were conducted in a concrete flume with a glass-walled viewing section. The flume measured $61 \mathrm{~m}$ long by $2.1 \mathrm{~m}$ deep and $1.5 \mathrm{~m}$ wide (200 ft by $7.0 \mathrm{ft}$ by $5.0 \mathrm{ft}$ ) and was equipped with a computer-controlled electro-hydraulic piston-type wave generator (Figure 5). A wall of 3/4-in. plywood was constructed lengthwise down the center of the flume to divide it into two symmetric $0.75-\mathrm{m}-(2.5-\mathrm{ft}-)$ wide sections. This was done so the two cross sections could be tested simultaneously.

The model was built at an undistorted linear scale of 1:24 (model: prototype), which was determined to be the largest scale for which the wave generator could reproduce the desired wave spectra. Hydrodynamics were modeled based on Froude similitude. All dimensions and results in this report are presented in prototype scale, with all elevations referenced to Low Water Datum (LWD) for Lake Michigan unless otherwise noted.

\section{Bathymetry}

Figure 6 was extracted from a National Oceanographic and Atmospheric Administration (NOAA) chart that shows the bathymetry of the study area. The slope approaching the shore for Section 1 was found to be roughly $1 \mathrm{~V}: 500 \mathrm{H}$. A flat (zero) slope was used for modeling purposes to represent this nearly flat offshore bathymetry. According to the original crosssection design, the depth at the toe of the revetment was to be $-3.66 \mathrm{~m}$ $(-12.0 \mathrm{ft})$, but during the initial phases of testing, in order to achieve a greater incident wave height at the structure, the depth at the revetment

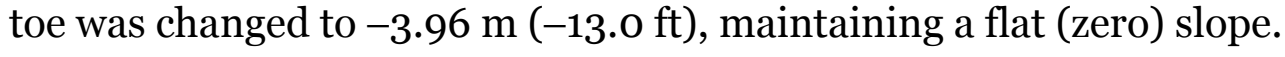




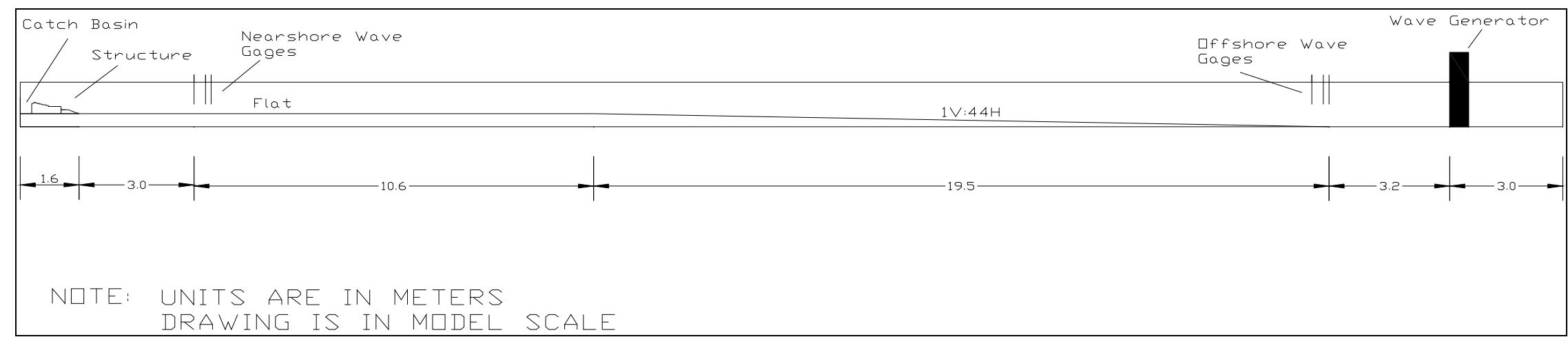

Figure 5 . Cross section of wave flume. 


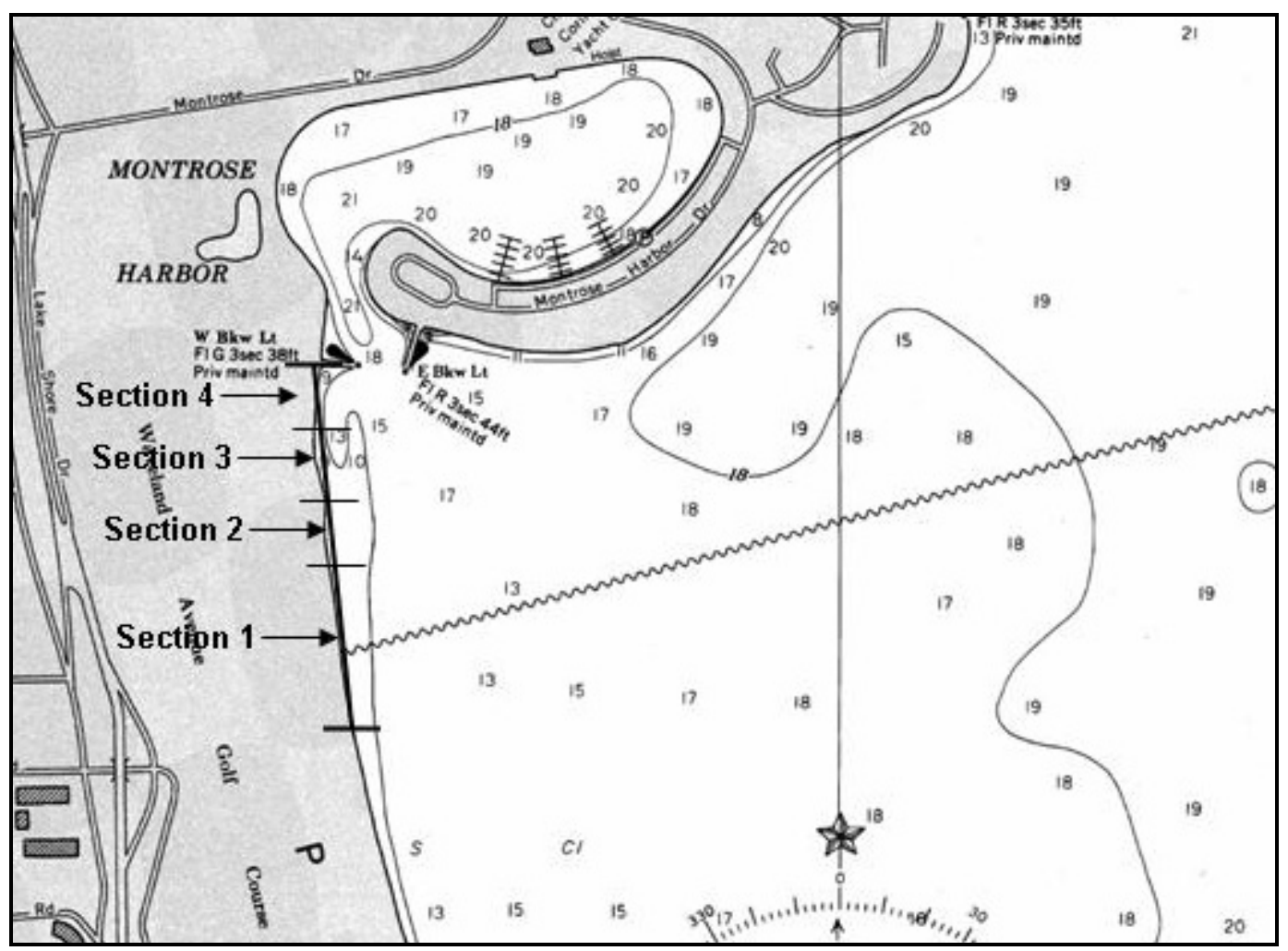

Figure 6. Bathymetry for Montrose to Irving Sections 1-4 (from NOAA Chart 14926).

\section{Revetment cross sections}

The Montrose to Irving reach was divided into four sections (Figure 6) based on preliminary overtopping estimates along the reach. Only one of the four sections (Section 1 in Figure 6) was tested in the physical model, but two alternatives for this section were tested. Designs between the four sections are similar, but there are slight variations in crest height and number of steps. Within a section, the two alternatives are geometrically similar. The difference between the two alternatives lies in the number of cut stone rows that will make up the crest, which will be constructed using the existing cut limestone blocks. Concrete portions of revetment cross sections were constructed of marine plywood and sealed to the sides of the flume. The limestone blocks were modeled by cutting scaled blocks out of stone with a density similar to that of limestone (differences in density were accounted for in the scaling of stones). The smooth sides of the cut stones were dimpled to create a more realistic surface texture and to give all the stones a unique final shape. Stone sizes were selected from an inventory completed by the Chicago District of the existing stones at the site. The stone sizes used in the model are listed in Table 1 . The cut stones 
were placed on a bed of 4-667 N (1-150 lbf) fill material that extended to the bottom of the flume. To ensure that no extra support was given to the cut stones, a gap of approximately $1.5 \mathrm{~m}$ (5.0 ft) was left landward of the cross section before a short splash apron transitioned down to a catch basin. Toe protection was constructed from a combination of two types of stone: $4-667 \mathrm{~N}$ (1-15o lbf) bedding stone with $23-69 \mathrm{kN}$ (2.6-7.8 ton) stone placed on top.

Table 1. Limestone block dimensions (prototype).

\begin{tabular}{|l|l|l|l|}
\hline $\begin{array}{l}\text { Size Range, } \\
\text { kN (ton) }\end{array}$ & $\begin{array}{l}\text { Length, } \\
\mathrm{m}(\mathrm{ft})\end{array}$ & $\begin{array}{l}\text { Width, } \\
\mathrm{m}(\mathrm{ft})\end{array}$ & $\begin{array}{l}\text { Height, } \\
\mathrm{m}(\mathrm{ft})\end{array}$ \\
\hline $27-36(3-4)$ \#1 & $1.7(5.4)$ & $0.55(1.8)$ & $1.1(3.6)$ \\
\hline $27-36(3-4)$ \#2 & $1.1(3.5)$ & $0.97(3.2)$ & $1.1(3.6)$ \\
\hline $36-45(4-5)$ \#1 & $1.9(6.4)$ & $0.55(1.8)$ & $1.2(4.1)$ \\
\hline $36-45(4-5)$ \#2 & $1.2(4.1)$ & $0.97(3.2)$ & $1.1(3.6)$ \\
\hline $36-45(4-5)$ \#3 & $1.1(3.6)$ & $1.1(3.6)$ & $1.1(3.6)$ \\
\hline $45-53(5-6)$ \#1 & $1.9(6.2)$ & $0.83(2.7)$ & $1.1(3.6)$ \\
\hline $45-53(5-6)$ \#2 & $1.5(4.8)$ & $0.97(3.2)$ & $1.2(3.6)$ \\
\hline $53-62(6-7)$ \#1 & $2.1(7.0)$ & $0.83(2.7)$ & $1.1(3.6)$ \\
\hline $53-62(6-7)$ \#2 & $1.6(5.4)$ & $1.1(3.6)$ & $1.1(3.6)$ \\
\hline $62-71(7-8)$ \#1 & $1.8(6.1)$ & $1.1(3.6)$ & $1.1(3.6)$ \\
\hline
\end{tabular}

Marine mattresses were incorporated into the cross section design prior to data collection to aid in the stability of bedding stone landward of the cut stone rows. The mattresses used were $8.8 \mathrm{~m}(29 \mathrm{ft})$ long by $1.5 \mathrm{~m}(5.0 \mathrm{ft})$ wide by $0.31 \mathrm{~m}(1.0 \mathrm{ft})$ thick and were filled with the $4-667 \mathrm{~N}$ (1-15o lbf) fill stone. Mattresses were constructed out of a pliable plastic mesh material that was cut to the above dimensions and stitched together with fishing line. More information about marine mattresses and their uses can be found in ERDC/CHL CHETN-III-72 (Hughes 2006). Figure 7 shows an overhead view of the two-stone row cross section as it was tested in the flume. Figures 8 and 9 depict the three-stone row and two-stone row designs as built in the flume, including toe protection. 


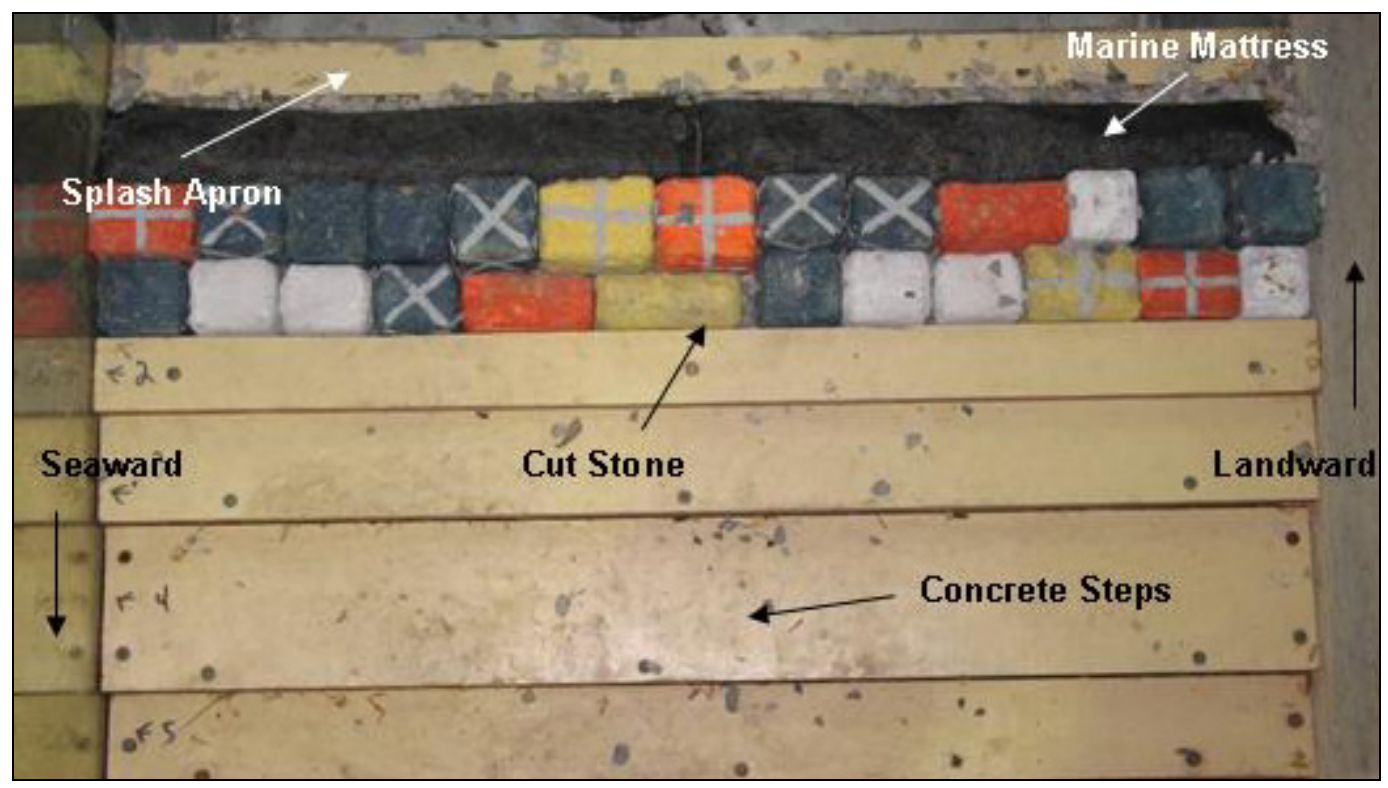

Figure 7. Direct overhead view of two-stone row cross section.

\section{Stone placement}

Both the two- and three-stone designs were constructed using the following methods. A bed of 4-667 N (1-150 lbf) fill material was laid behind the concrete steps of the structure. In both designs, the most seaward row was placed first. In this row, each stone was placed vertically, flush with the top concrete step, and adjusted to the correct elevation. Cut stones were placed in succession along the concrete step for the width of the flume and were firmly set into the bedding material. A very small gap between the final stone in a row and the flume wall was maintained to avoid any impact of the rigid wall. Bedding material routinely had to be re-laid or shifted to place the stones at the correct elevations. The heights of the cut stones were not consistent, so a single flat layer of bedding material was not appropriate for stone placement.

The second and third, or landward rows of stones, were placed similarly to the most seaward row except that not all stones could be placed flush with the seaward row because of the varying sizes and dimensions of the stones. Each stone was placed as close as possible to the seaward stone, but there were some gaps between rows. The small voids resulting from the variation in stone size were filled with the 4-667 N (1-15o lbf) stone. Figures 10 and 11, respectively, show the configurations in which stones were placed for the two- and three-stone designs during construction. 


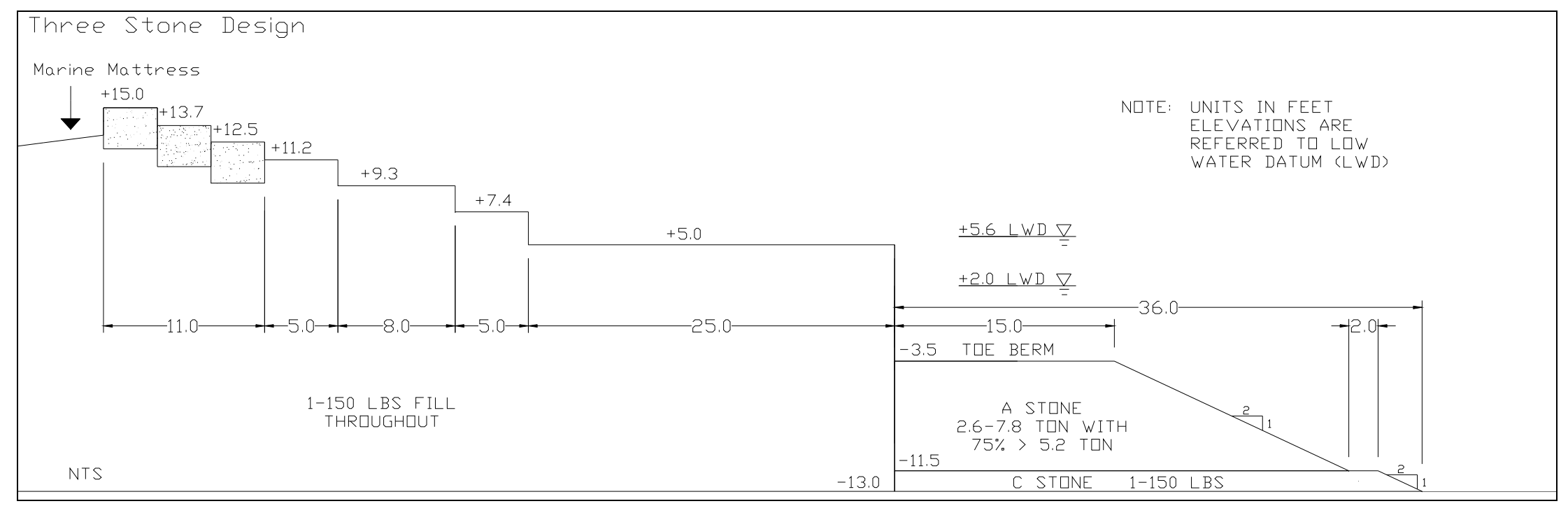

Figure 8. Three-stone row cross section as built in the flume.

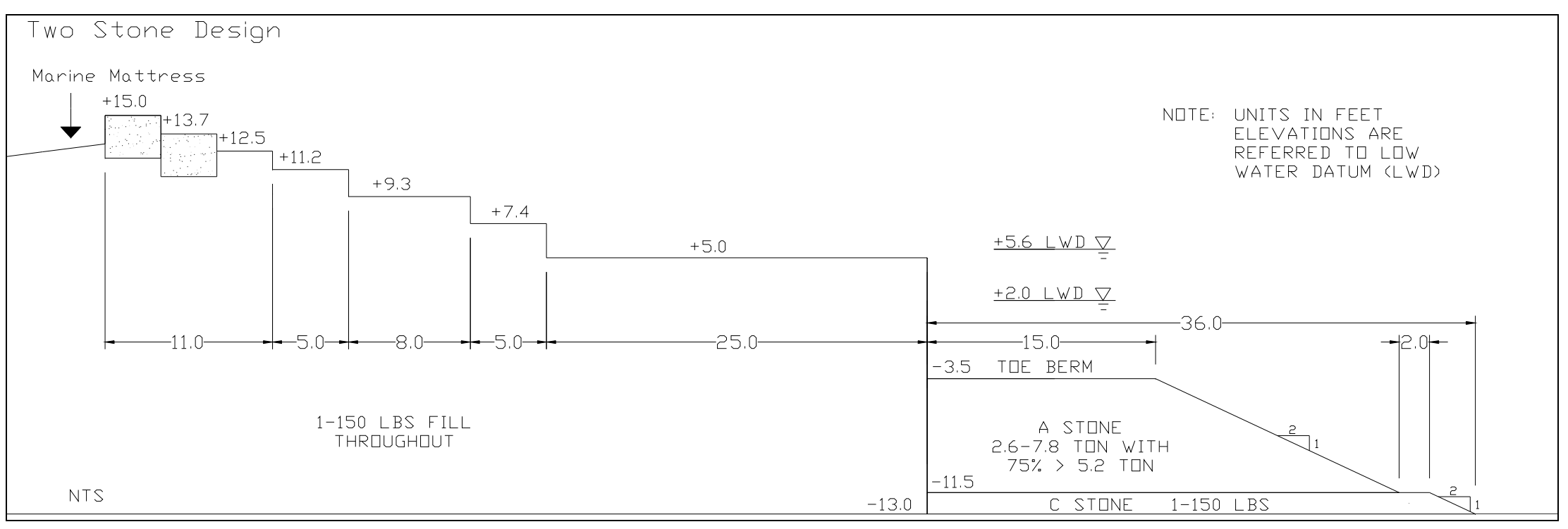

Figure 9. Two-stone row cross section as built in the flume. 


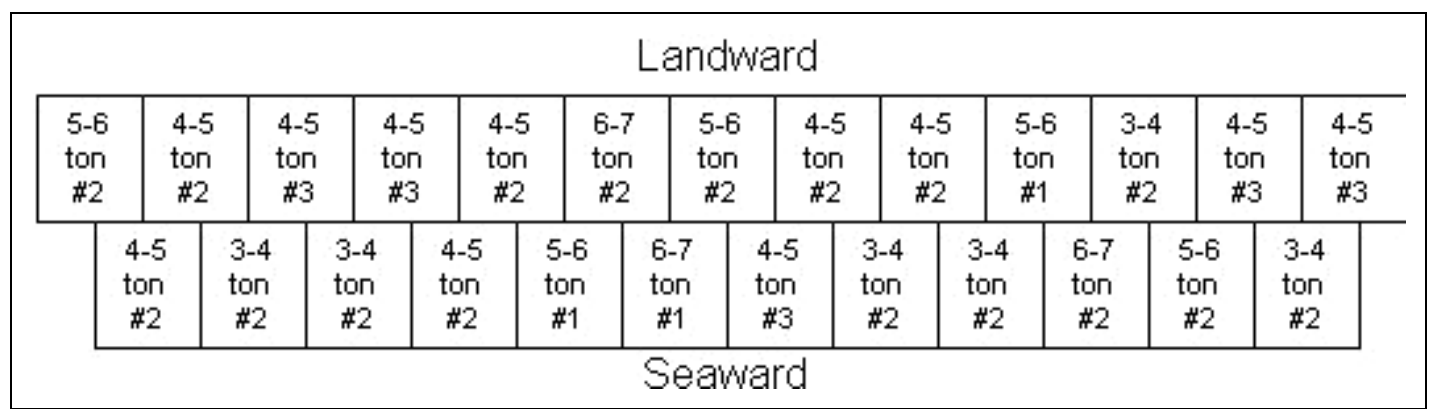

Figure 10. Stone placement for two-stone row design ( 1 ton $=8.9 \mathrm{kN})$.

\begin{tabular}{|c|c|c|c|c|c|c|c|c|c|c|c|c|}
\hline \multicolumn{13}{|c|}{ Leeward } \\
\hline $\begin{array}{c}4-5 \\
\text { ton } \\
\# 3\end{array}$ & $\begin{array}{c}3-4 \\
\text { ton } \\
\# 2\end{array}$ & $\begin{array}{c}3-4 \\
\text { ton } \\
\# 2\end{array}$ & $\begin{array}{c}6-7 \\
\text { ton } \\
\# 1\end{array}$ & $\begin{array}{c}3-4 \\
\text { ton } \\
\# 2\end{array}$ & $\begin{array}{c}4-5 \\
\text { ton } \\
\$ 3\end{array}$ & $\begin{array}{c}3-4 \\
\text { ton } \\
\# 2\end{array}$ & $\begin{array}{c}4-5 \\
\text { ton } \\
\# 3\end{array}$ & $\begin{array}{c}3-4 \\
\text { ton } \\
\# 2\end{array}$ & $\begin{array}{c}4-5 \\
\text { ton } \\
\# 2\end{array}$ & $\begin{array}{c}3-4 \\
\text { ton } \\
\# 2\end{array}$ & $\begin{array}{c}4-5 \\
\text { ton } \\
\# 3\end{array}$ & $\begin{array}{c}4-5 \\
\text { ton } \\
\# 3\end{array}$ \\
\hline & $\begin{array}{c}5-6 \\
\text { ton } \\
\# 1\end{array}$ & $\begin{array}{c}4-5 \\
\text { ton } \\
\# 3\end{array}$ & $\begin{array}{c}3-4 \\
\text { ton } \\
\# 2\end{array}$ & $\begin{array}{c}4-5 \\
\text { ton } \\
\# 2\end{array}$ & $\begin{array}{c}3-4 \\
\text { ton } \\
\# 1^{*}\end{array}$ & $\begin{array}{c}3-4 \\
\text { ton } \\
\# 2\end{array}$ & $\begin{array}{c}6-7 \\
\text { ton } \\
\# 2\end{array}$ & $\begin{array}{c}4-5 \\
\text { ton } \\
\# 3\end{array}$ & $\begin{array}{c}6-7 \\
\text { ton } \\
\# 2\end{array}$ & $\begin{array}{c}6-7 \\
\text { ton } \\
\# 1\end{array}$ & $\begin{array}{c}5-6 \\
\text { ton } \\
\# 1\end{array}$ & \\
\hline & $\begin{array}{c}7-8 \\
\text { ton } \\
\# 1\end{array}$ & $\begin{array}{c}6-7 \\
\text { ton } \\
\# 2\end{array}$ & $\begin{array}{c}7-8 \\
\text { ton } \\
\# 2\end{array}$ & $\begin{array}{c}6-7 \\
\text { ton } \\
\# 1\end{array}$ & $\begin{array}{c}5-6 \\
\text { ton } \\
\# 1\end{array}$ & $\begin{array}{c}5-6 \\
\text { ton } \\
\# 2\end{array}$ & $\begin{array}{c}4-5 \\
\text { ton } \\
\# 2\end{array}$ & $\begin{array}{c}3-4 \\
\text { ton } \\
\# 2\end{array}$ & $\begin{array}{c}4-5 \\
\text { ton } \\
\# 3\end{array}$ & $\begin{array}{c}5-6 \\
\text { ton } \\
\# 2\end{array}$ & $\begin{array}{r}4-5 \\
\text { ton } \\
\$ 3\end{array}$ & \\
\hline
\end{tabular}

Figure 11. Stone placement for three-stone row design, 1* denotes two $27-36 \mathrm{kN}$ (3-4 ton) \#1 stones that were placed to act as one stone $(1$ ton $=8.9 \mathrm{kN})$.

Based on guidance from the Chicago District, stones of varying sizes were placed in each row. Generally, the larger stones were placed seaward on the structure and the smaller stones were placed landward. In some cases, smaller stones were required in seaward rows in order to fill in spaces too small for larger stones. There was no specific order in which stones were placed and stones were chosen at random from the available supply, in an attempt to replicate likely construction scenarios.

\section{Storm waves and water levels}

Overtopping rates for coastal structures depend on water level, incident wave height, and period. For the Montrose to Irving reach, the Chicago District selected a 10-year return period lake level to be modeled with a 20-year return period storm event (a storm having a significant wave height that will be equaled or exceeded, on average, once every 20 years). The Chicago District also elected to model a 2-year storm event with a $+0.61 \mathrm{~m}(+2.0 \mathrm{ft})$ lake level to determine the effects of a more frequent, 
less severe storm. Wave height and period for the 2- and 20-year storms as well as water levels for both conditions were provided by the Chicago District and are listed in Table 2. The wave height statistic used is the incident spectral significant wave height, $H_{m 0}=4\left(m_{0}\right)^{1 / 2}$, where $m_{0}$ is the zeroth moment of the incident wave spectrum, and wave period is the peak wave period, $T_{p}$, corresponding to the inverse of the peak frequency of the incident wave spectrum. Wave height and period for the 2- and 20-year storms were based on wave hindcast information at a 13-m (43-ft) depth. Waves were generated using the Joint North Sea Wave Project Spectrum (Hasselmann et al. 1973) with a spectral spreading coefficient of 3.3. Overtopping was pumped out of the catch basin into containers and measured throughout each test. Once measured, the water from the catch basins was pumped back into the flume at regular intervals to keep the lake level constant during each test.

Table 2. Storm waves and water levels (prototype).

\begin{tabular}{|l|l|l|l|}
\hline $\begin{array}{l}\text { Return Period } \\
\text { years }\end{array}$ & $\begin{array}{l}\text { Water Level } \\
\mathrm{m}(\mathrm{ft})\end{array}$ & $\begin{array}{l}\text { Wave Height, } H_{m 0} \\
\mathrm{~m}(\mathrm{ft})\end{array}$ & $\begin{array}{l}\text { Wave Period } T_{p} \\
\text { sec }\end{array}$ \\
\hline 2 & $+0.61(+2.0)$ & $5.00(16.4)$ & 11.7 \\
\hline 20 & $+1.71(+5.6)$ & $6.10(20.0)$ & 12.8 \\
\hline
\end{tabular}




\section{Results and Discussion}

\section{Qualitative testing}

Prior to data collection, while wave calibration was taking place, several problems arose and were addressed. Before marine mattresses were included in the design, a plywood splash apron measuring approximately $1.83 \mathrm{~m}$ (6.o ft) wide ran along the landward side of the cross section behind the crest. This was included to direct the overtopping splash into the catch basin. Concern was expressed that the splash apron would provide extra support to the cut stones, so the width was reduced to approximately $0.61 \mathrm{~m}$ (2.0 ft), exposing fill material behind the cut stones. During an initial testing run, on which overtopping was not collected nor video taken, the wave overtopping caused this fill material to be washed out from behind the crest, leaving large, irregular voids along the landward length of the structure. As the material was washed out, the cut stones were pushed landward into the voids, causing significant damage to the crest of the structure, resulting in loss of the design crest elevation. Upon discussion with the Chicago District, it was decided that marine mattresses would be placed behind the most landward row of stones to provide a filter layer over the fill material.

Also prior to data collection, it was noted that stones with a significantly smaller height than width shifted more easily than stones that had similar height and width dimensions. For example, a $27-36 \mathrm{kN}$ (3-4 ton) \#1 stone as defined in Table 1, placed with the width dimension in the y-direction, the height dimension in the $\mathrm{x}$-direction (with the $\mathrm{x}$-direction across the flume, and the y-direction vertical), the length perpendicular to the observer's line of site and the waves also perpendicular to the observer, shifted more easily than the same stone placed with the height dimension in the $\mathrm{y}$-direction and the width dimension in the $\mathrm{x}$-direction. During one wave calibration run it was observed that a stone placed in the first orientation mentioned (width in the y-direction, height in the x-direction) flipped off the top of the crest by wave action. The specific wave data associated with this event were not recorded. 


\section{Stone stability}

\section{0-year storm}

A simulated storm hydrograph was used to ramp up to the design wave condition. Waves with heights of $25,50,70,85$, and 100 percent of the design $H_{m o}$ (Table 2) were run in the flume for 15 min each (model time). This equates to a storm segment length of 74 min prototype, with the entire storm hydrograph lasting $6.1 \mathrm{hr}$. Stone movement was first observed during the 50 percent run. Several stones in the most landward row began to lean slightly against the mattresses, but both the two- and three-stone row structures remained intact. During the 70 percent run, the three-stone row design showed slightly more damage. The back row continued to lean landward, and there was visible sagging in the center of the row. Stones in the middle row also started to lean against the back row. During the 85 and 100 percent runs, stones in the landward rows of each structure continued to shift and lean, but the seaward rows of both structures showed no signs of movement. Underlayer material that filled the gaps between stones was washed out, but during testing, no stone moved beyond a repairable limit state.

Figures 12, 13, and 14 show before and after photographs of the cross sections, including the cut stone rows and marine mattresses, from one of the 20-year event tests. One test and one repeat were run for this storm event, with the structure being rebuilt between the first and second test series. The structure performed similarly in both test series. Based on the observations from this event, it is recommended that stones no smaller than $35.6-44.5 \mathrm{kN}$ (4-5 tons) be used in construction of the seaward steps and that all stones in the structure be no smaller than $26.7-35.6 \mathrm{kN}$ (3-4 tons) for the design conditions. Data are not available for designs other than those used in these experiments, and it is unknown how smaller and/or larger stones would react to the conditions tested. 


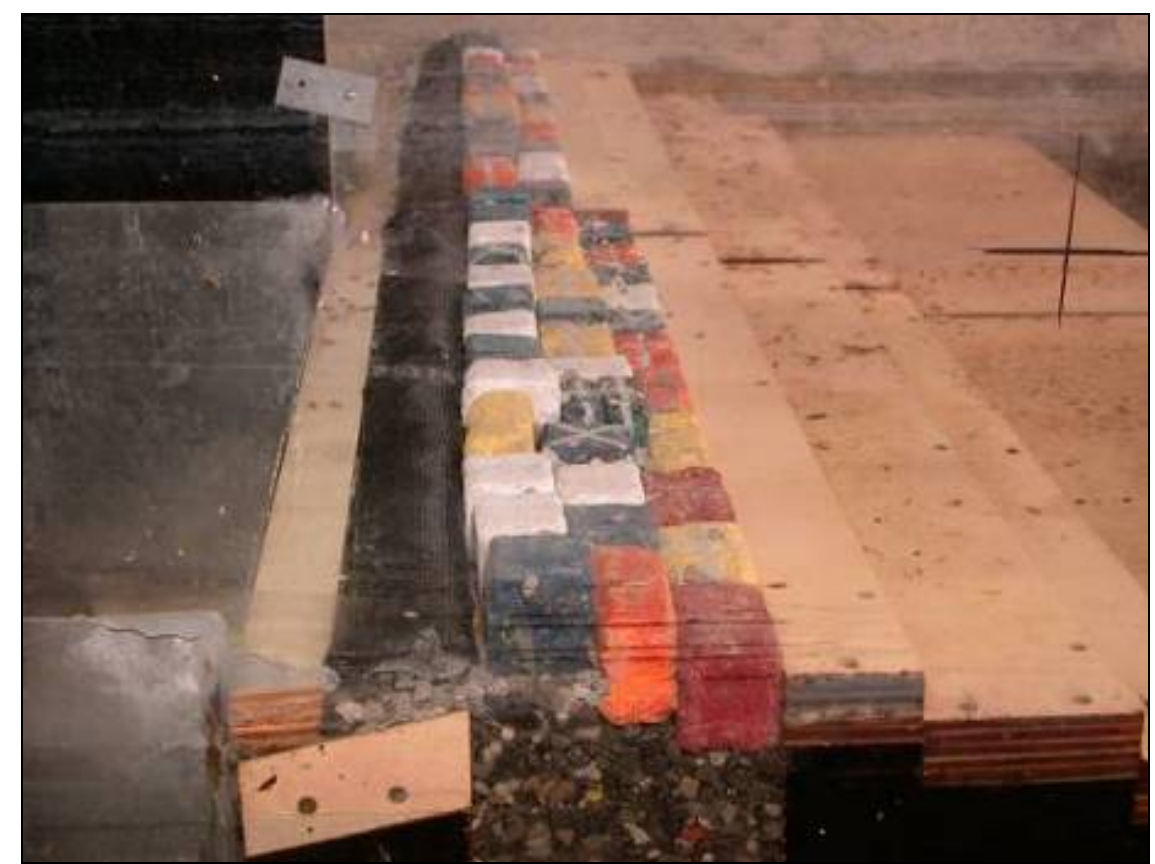

(a) Before storm.

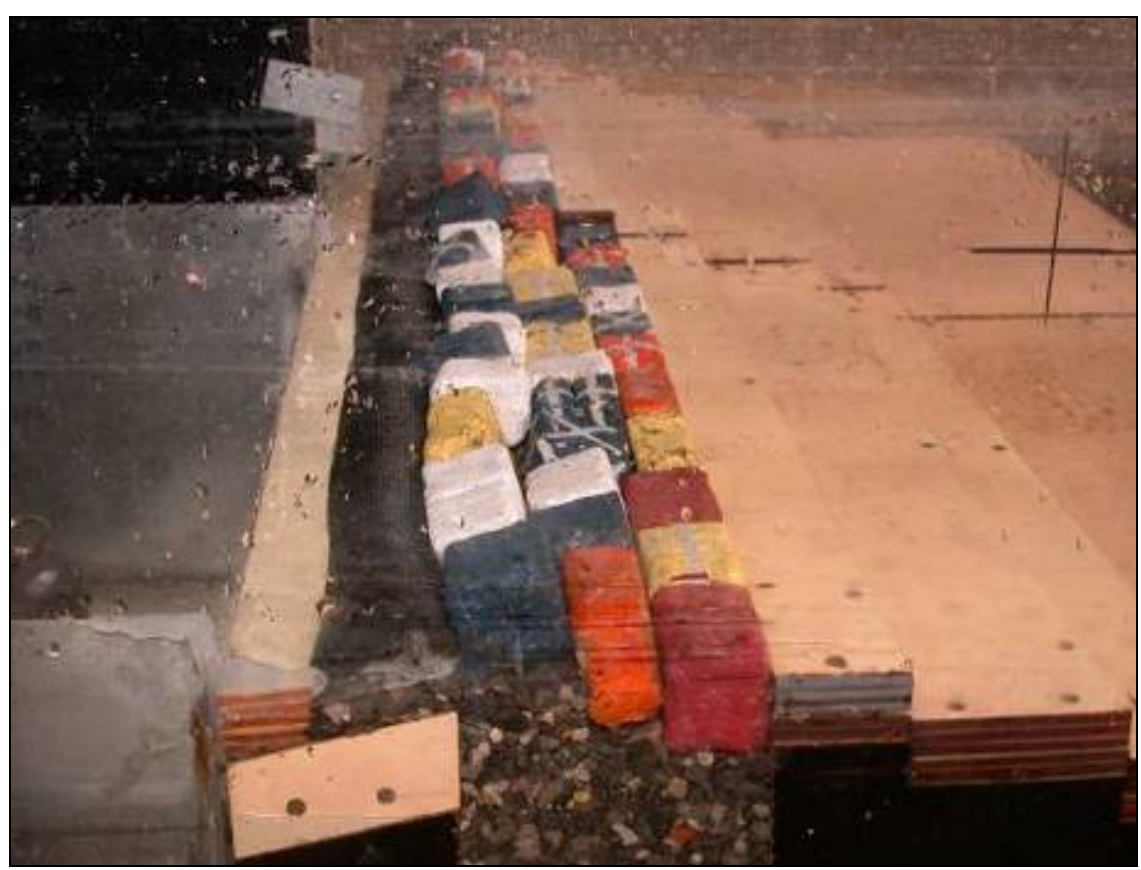

(b) After storm.

Figure 12. Side photographs from before and after the 20-year storm event (three- and two-stone row structures are separated by a plexiglass wall, with three-stone row structure closest to observer and two-stone structure on far side of flume). 


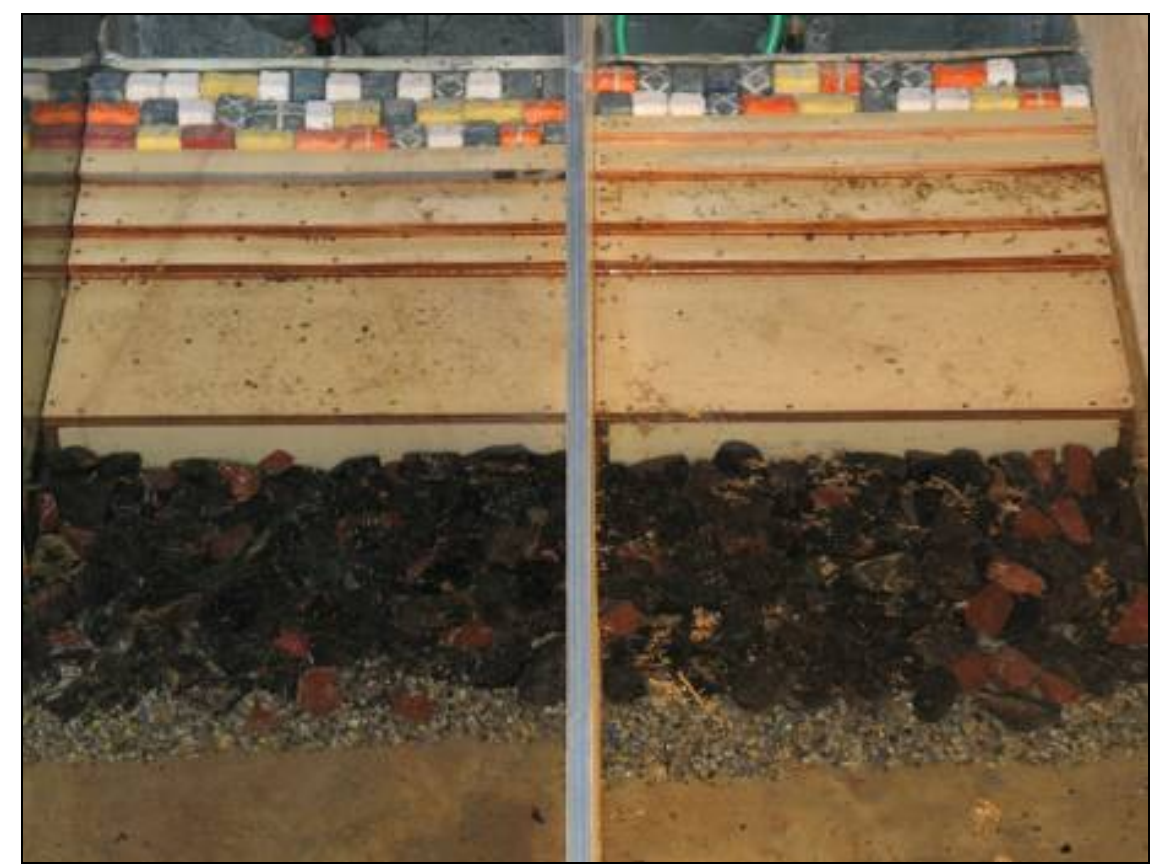

(a) Before storm.

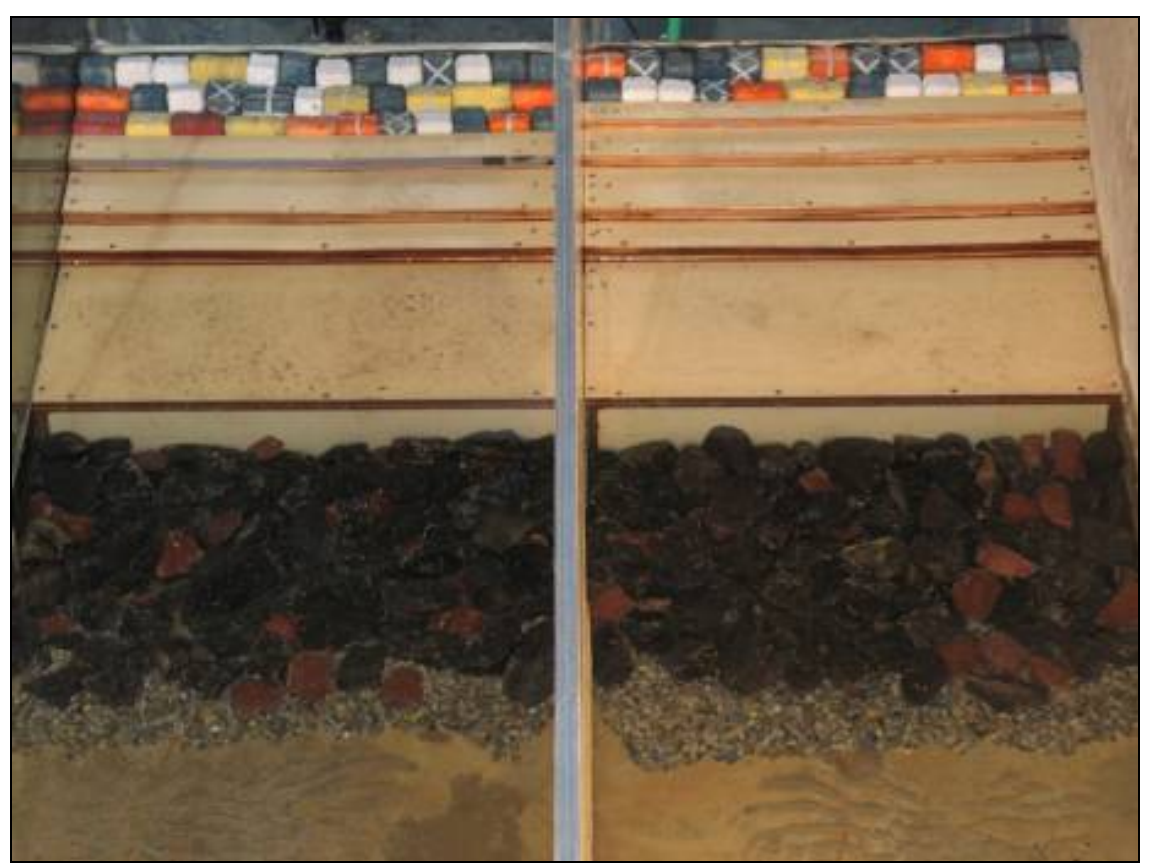

(b) After storm.

Figure 13. Overhead photographs from before and after the 20-year storm event (three-stone row design is on left and two-stone row design on right). 


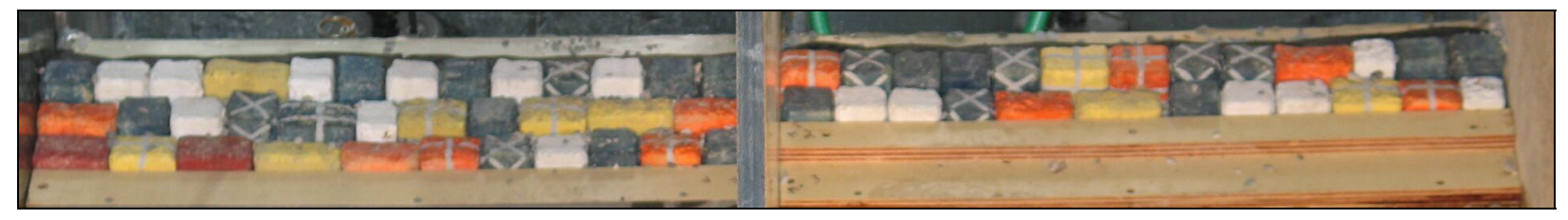

(a) Before storm.

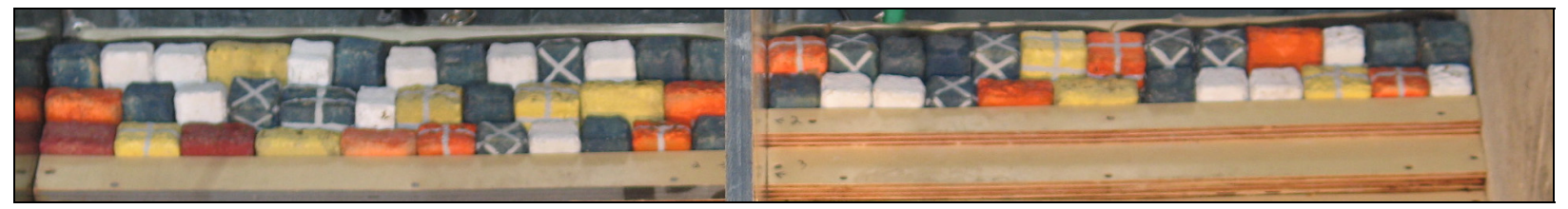

(b) After storm.

Figure 14. Overhead photographs from before and after the 20-year storm event zoomed in on cut stone rows (three-stone row design is on left and two-stone row design on right).

\section{2-year storm}

Similar to the 20-year storm, a simulated storm hydrograph was used for the 2-year storm event. The same percentages of design $H_{m o}$ were used to build up to the maximum wave. During the simulated storm, no significant stone movement on the structures was observed. Fill material from gaps between the stones did wash out, but not to the extent that was observed during the 20-year storm. Before and after photographs of the cross sections, including the cut stone rows and marine mattresses, from the 2-year event are shown in Figure 15 (side) and Figures 16 and 17 (overhead).

\section{Overtopping observations}

Overtopping was captured in watertight metal catch basins located landward of each structure. The water was pumped out of the catch basins at regular intervals, and volumes were recorded. Once measurements had been taken, the water was pumped back into the flume to keep the water level constant during the test. Despite having the same crest elevations, the three-stone row design consistently had more overtopping than the two-stone row design. The overtopping difference between the two designs does not fall outside the range of scatter in the data and is therefore not significant. The flat slope approaching the structure produced a large surf zone, which resulted in many of the waves breaking before reaching the structure. Significant reflection was also observed during testing because of waves hitting the vertical face of the structure. 


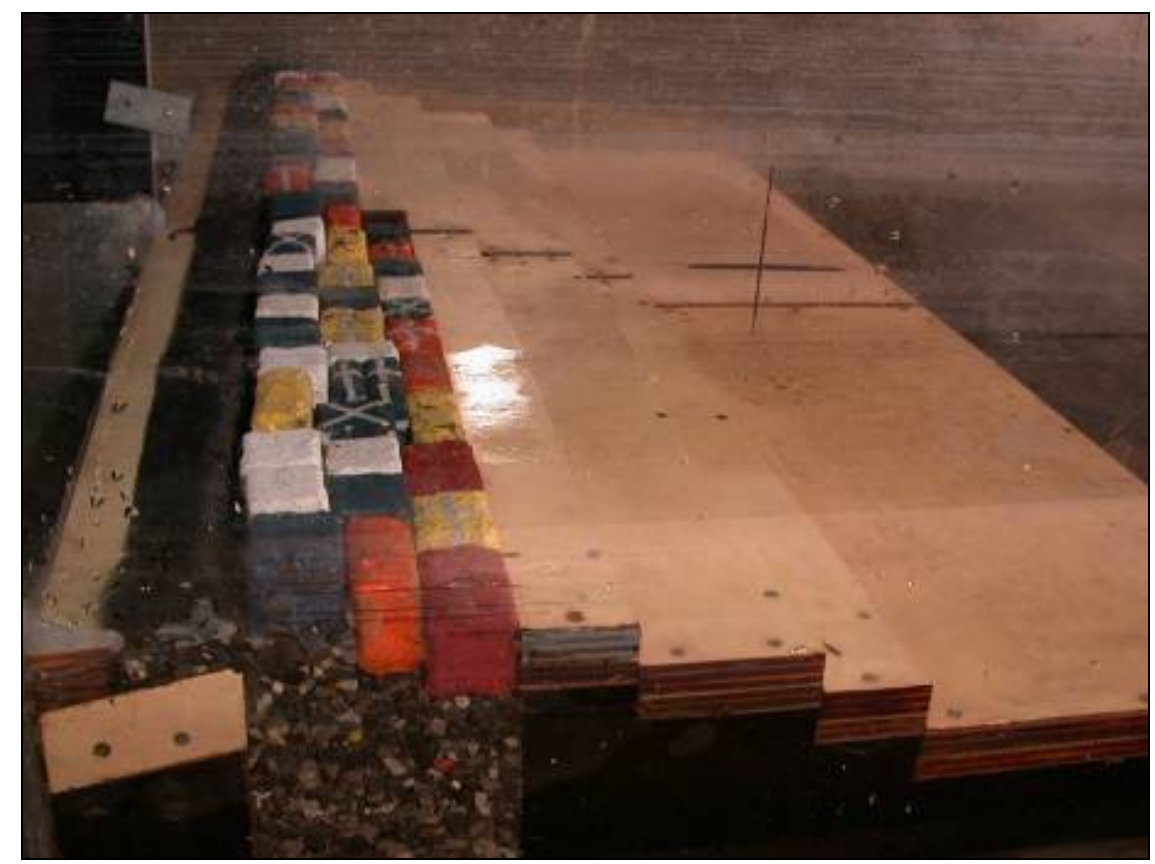

(a) Before storm.

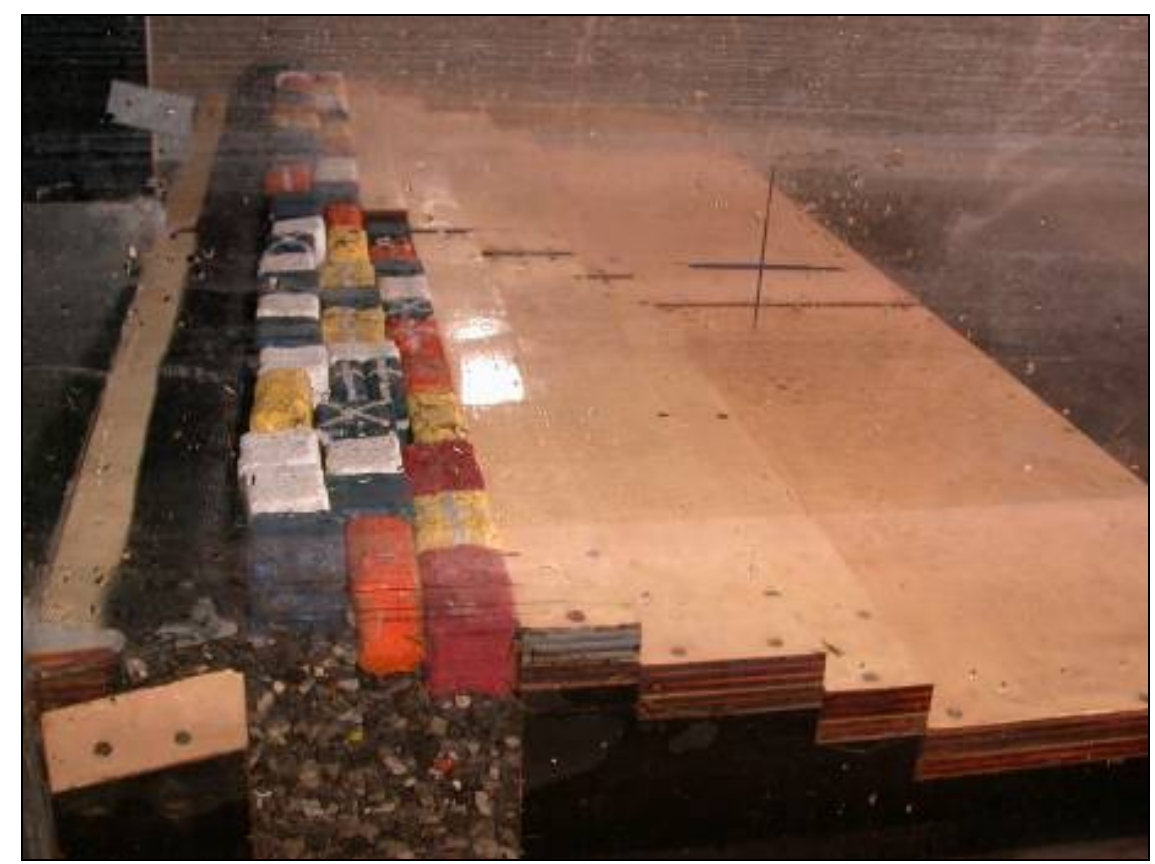

(b) After storm.

Figure 15. Side photographs from before and after the 2-year storm event. 


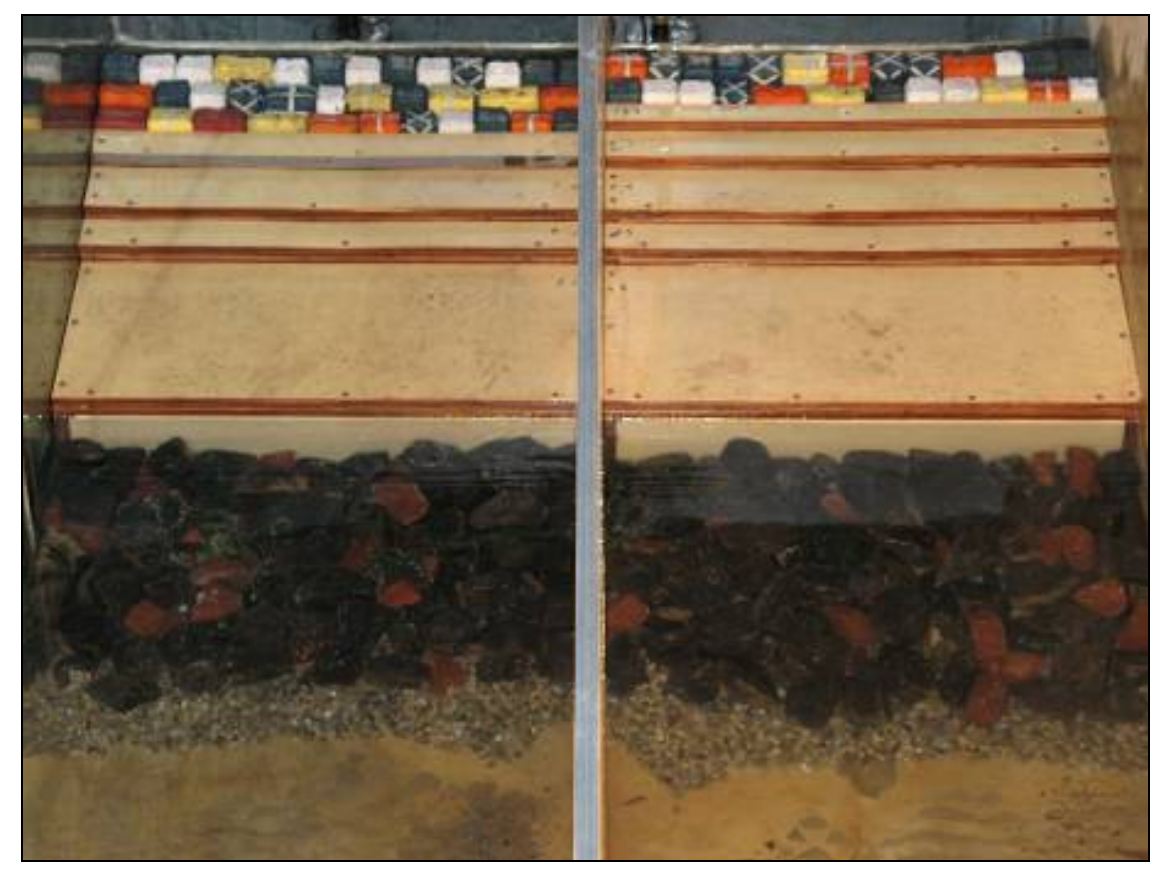

(a) Before storm.

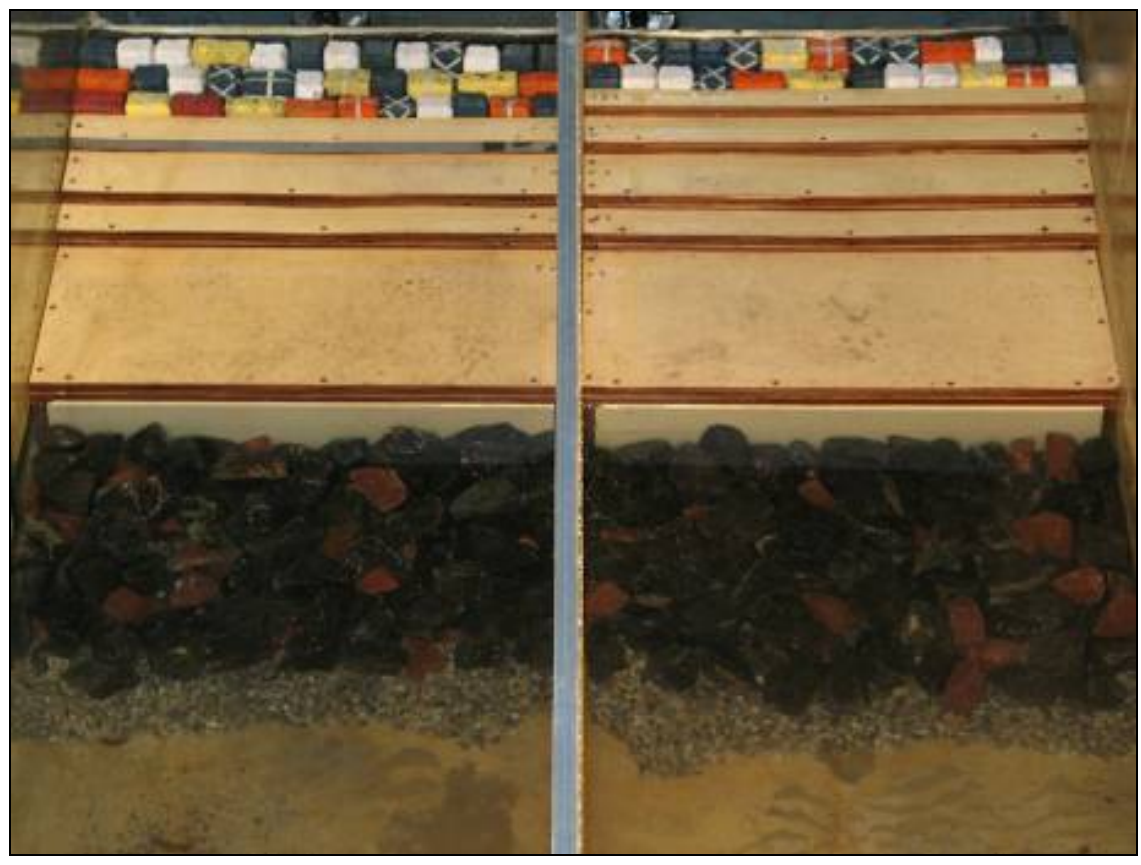

(b) After storm.

Figure 16. Overhead photographs from before and after the 2-year storm event. 


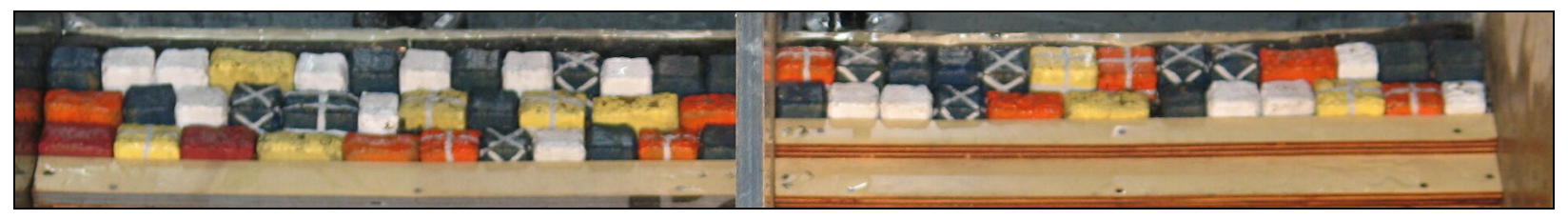

(a) Before storm.

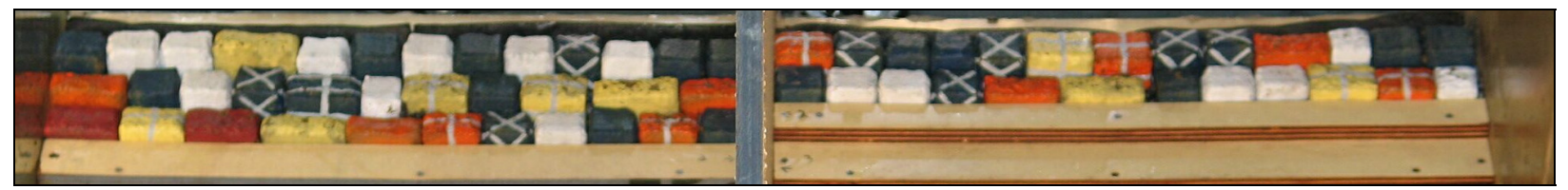

(b) After storm.

Figure 17. Overhead photographs from before and after the 2-year storm event zoomed in on cut stone rows.

\section{0-year storm}

During the 20-year event, measurable overtopping was observed when waves reached 50 percent of the design $H_{m o}$. At this point in the simulated storm, approximately every fifth wave overtopped the crest of the structure. At the peak of the storm, nearly every wave overtopped the structure, either plunging directly into the catch basin or hitting the splash apron located behind the crest. Figure 18 shows runup on the revetment's concrete steps that frequently occurred during this event. Based on measurements made during the tests, if the catch basins had not been installed behind the structures and a flat surface had instead been in place, plunging waves would have impacted up to $3.1 \mathrm{~m}$ (10.0 ft) behind the structure crest (Figure 19). The overtopping rate at the peak of the storm was found to be approximately $0.06 \mathrm{cu} \mathrm{m} / \mathrm{sec}-\mathrm{m}(0.62 \mathrm{cu} \mathrm{ft} / \mathrm{sec}-\mathrm{ft})$ for the threestone row design and $0.05 \mathrm{cu} \mathrm{m} / \mathrm{sec}-\mathrm{m}(0.53 \mathrm{cu} \mathrm{ft} / \mathrm{sec}-\mathrm{ft})$ for the two-stone row design. Table 3 provides wave information and overtopping rates for the 20-year storm. The offshore incident wave height is the measured wave height approximately $794 \mathrm{~m}(2,605 \mathrm{ft})$ seaward of the structure toe, and the nearshore incident wave height is the measured wave height approximately $72 \mathrm{~m}(236 \mathrm{ft}$ ) seaward of the structure toe. 


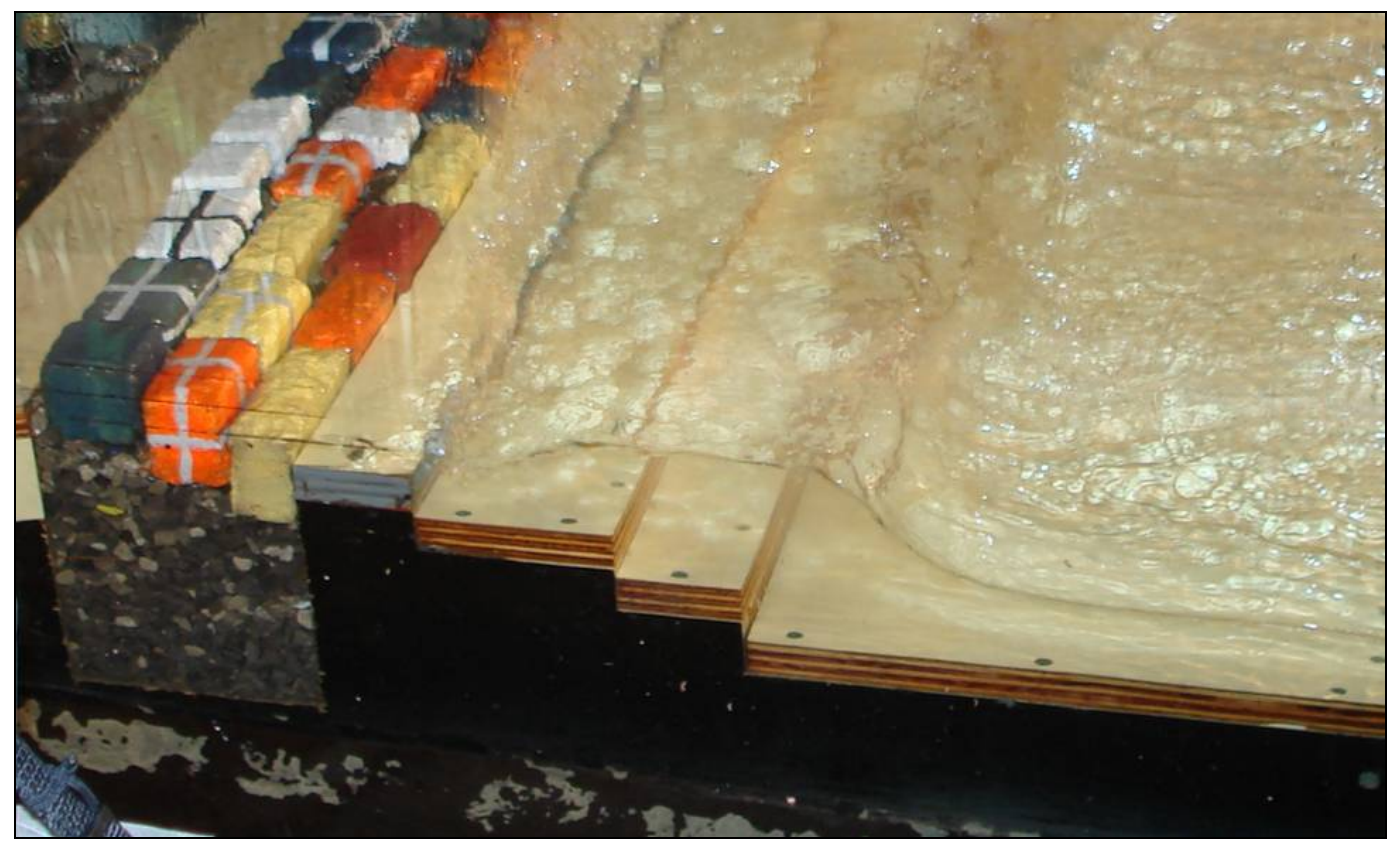

Figure 18. Wave runup on concrete steps (prior to marine mattresses being installed) (photograph courtesy of Drew Benziger, Chicago District).

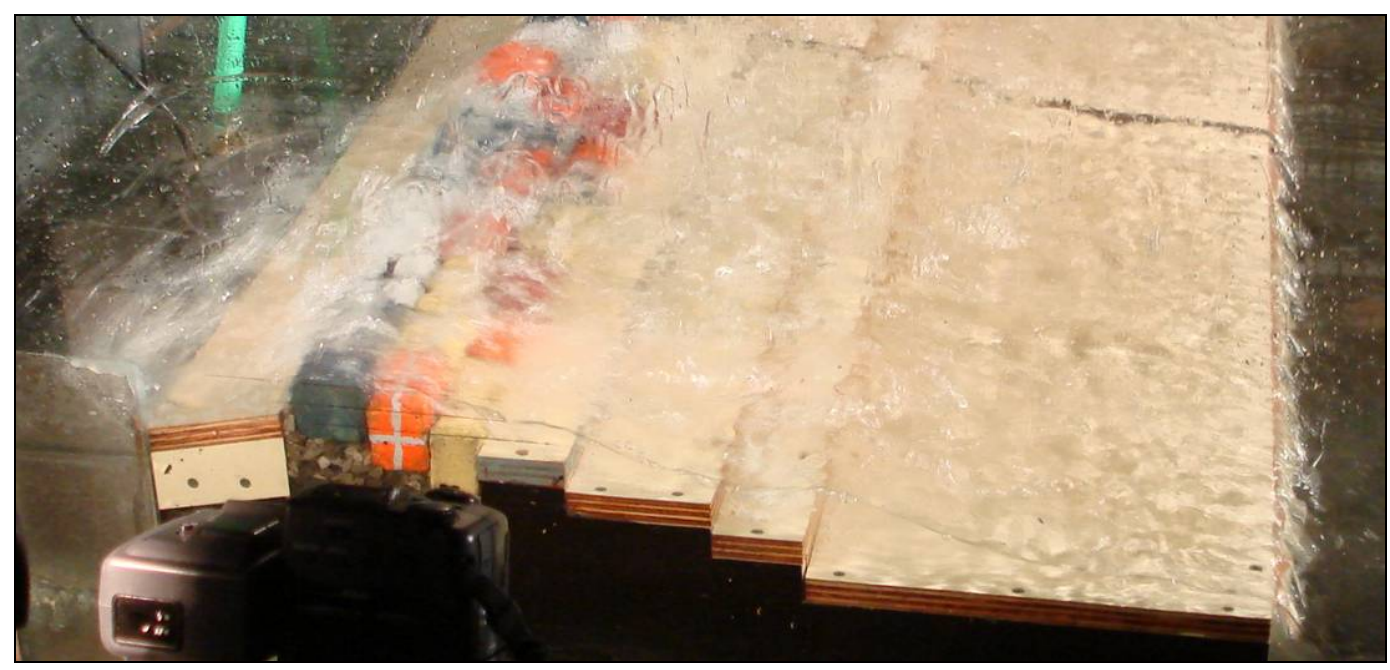

Figure 19. Wave overtopping three-stone row structure (prior to marine mattresses being installed) (photograph courtesy of Drew Benziger, Chicago District). 
Table 3. Wave properties and overtopping rates for 20-year storm.

\begin{tabular}{|c|c|c|c|c|c|c|c|c|c|}
\hline \multirow[b]{2}{*}{ Test } & \multirow{2}{*}{$\begin{array}{l}\text { Percent of } \\
\text { Target } H_{m 0}\end{array}$} & \multirow{2}{*}{$\begin{array}{l}\text { Duration } \\
t, \sec (\min )\end{array}$} & \multirow{2}{*}{$\begin{array}{l}\text { Offshore Incident } \\
\text { Wave Height } \\
H_{m 0}, \mathrm{~m} \text { (ft) }\end{array}$} & \multirow{2}{*}{$\begin{array}{l}\text { Nearshore Incident } \\
\text { Wave Height } \\
H_{m 0}, \mathrm{~m} \text { (ft) }\end{array}$} & \multirow{2}{*}{$\begin{array}{l}\text { Peak Wave } \\
\text { Period } \\
T_{p}, \text { sec }\end{array}$} & \multicolumn{2}{|c|}{$\begin{array}{l}\text { Instantaneous Overtopping } q \text {, } \\
\text { cu m/sec-m (cu ft/sec-ft) }\end{array}$} & \multicolumn{2}{|c|}{$\begin{array}{c}\text { Total Overtopping } \\
\mathrm{Q}, \mathrm{cu} \mathrm{m} / \mathrm{sec} \text { (cu ft/sec) }\end{array}$} \\
\hline & & & & & & 2 Stone & 3 Stone & 2 Stone & 3 Stone \\
\hline \multirow[t]{5}{*}{ First run } & 23 & 4409 (73.5) & $1.39(4.55)$ & $1.53(5.02)$ & 12.79 & $\begin{array}{l}0.00 \mathrm{E}+0 \\
(0.00 \mathrm{E}+0)\end{array}$ & $\begin{array}{l}0.00 \mathrm{E}+0 \\
(0.00 \mathrm{E}+0)\end{array}$ & $\begin{array}{l}0.00 \mathrm{E}+0 \\
(0.00 \mathrm{E}+0)\end{array}$ & $\begin{array}{l}0.00 E+0 \\
(0.00 E+0)\end{array}$ \\
\hline & 46 & 4409 (73.5) & 2.83 (9.29) & $2.52(8.27)$ & 12.79 & $\begin{array}{l}2.26 \mathrm{E}-2 \\
(2.41 \mathrm{E}-1)\end{array}$ & $\begin{array}{l}3.12 \mathrm{E}-2 \\
(3.36 \mathrm{E}-1)\end{array}$ & $\begin{array}{l}4.07 \mathrm{E}-1 \\
(1.44 \mathrm{E}+1)\end{array}$ & $\begin{array}{l}5.63 \mathrm{E}-1 \\
(1.99 \mathrm{E}+1)\end{array}$ \\
\hline & 67 & 4409 (73.5) & 4.08 (13.39) & $2.54(8.35)$ & 12.79 & \begin{tabular}{|l|}
$3.48 \mathrm{E}-2$ \\
$(3.74 \mathrm{E}-1)$ \\
\end{tabular} & \begin{tabular}{|l|}
$4.33 \mathrm{E}-2$ \\
$(4.67 \mathrm{E}-1)$
\end{tabular} & \begin{tabular}{|l|}
$6.28 \mathrm{E}-1$ \\
$(2.22 \mathrm{E}+1)$ \\
\end{tabular} & \begin{tabular}{|l|}
$7.83 \mathrm{E}-1$ \\
$(2.76 \mathrm{E}+1)$
\end{tabular} \\
\hline & 80 & 4409 (73.5) & 4.87 (15.98) & $2.47(8.11)$ & 12.79 & \begin{tabular}{|l|}
$4.43 \mathrm{E}-2$ \\
$(4.77 \mathrm{E}-1)$
\end{tabular} & $\begin{array}{l}5.31 \mathrm{E}-2 \\
(5.71 \mathrm{E}-1)\end{array}$ & $\begin{array}{l}8.00 \mathrm{E}-1 \\
(2.83 \mathrm{E}+1)\end{array}$ & $\begin{array}{l}9.59 \mathrm{E}-1 \\
(3.39 \mathrm{E}+1)\end{array}$ \\
\hline & 98 & 4409 (73.5) & 5.95 (19.53) & $2.47(8.11)$ & 12.79 & \begin{tabular}{|l|}
$5.29 \mathrm{E}-2$ \\
$(5.70 \mathrm{E}-1)$ \\
\end{tabular} & \begin{tabular}{|l|}
$5.60 \mathrm{E}-2$ \\
$(6.02 \mathrm{E}-1)$ \\
\end{tabular} & \begin{tabular}{|l|}
$9.56 \mathrm{E}-1$ \\
$(3.38 \mathrm{E}+1)$ \\
\end{tabular} & \begin{tabular}{|l}
$1.01 \mathrm{E}+0$ \\
$(3.57 \mathrm{E}+1)$
\end{tabular} \\
\hline \multirow[t]{5}{*}{ Repeat } & 24 & 4409 (73.5) & $1.46(4.78)$ & $1.53(5.02)$ & 12.79 & $\begin{array}{l}0.00 E+0 \\
(0.00 E+0)\end{array}$ & $\begin{array}{l}0.00 E+0 \\
(0.00 E+0)\end{array}$ & $\begin{array}{l}0.00 E+0 \\
(0.00 E+0)\end{array}$ & $\begin{array}{l}0.00 E+0 \\
(0.00 E+0)\end{array}$ \\
\hline & 49 & 4409 (73.5) & $2.98(9.76)$ & $2.52(8.27)$ & 12.79 & \begin{tabular}{|l|}
$2.03 \mathrm{E}-2$ \\
$(2.18 \mathrm{E}-1)$
\end{tabular} & $\begin{array}{l}2.84 \mathrm{E}-2 \\
(3.05 \mathrm{E}-1)\end{array}$ & $\begin{array}{l}3.66 \mathrm{E}-1 \\
(1.29 \mathrm{E}+1)\end{array}$ & \begin{tabular}{|l}
$5.13 \mathrm{E}-1$ \\
$(1.81 \mathrm{E}+1)$
\end{tabular} \\
\hline & 70 & 4409 (73.5) & 4.27 (14.02) & $2.76(9.06)$ & 12.79 & \begin{tabular}{|l|}
$2.93 \mathrm{E}-2$ \\
$(3.16 \mathrm{E}-1)$
\end{tabular} & $\begin{array}{l}4.22 \mathrm{E}-2 \\
(4.55 \mathrm{E}-1)\end{array}$ & $\begin{array}{l}5.30 \mathrm{E}-1 \\
(1.87 \mathrm{E}+1)\end{array}$ & $\begin{array}{l}7.63 \mathrm{E}-1 \\
(2.69 \mathrm{E}+1)\end{array}$ \\
\hline & 83 & 4409 (73.5) & 5.06 (16.61) & $2.45(8.03)$ & 12.79 & $\begin{array}{l}4.08 \mathrm{E}-2 \\
(4.39 \mathrm{E}-1)\end{array}$ & $\begin{array}{l}5.59 \mathrm{E}-2 \\
(6.01 \mathrm{E}-1)\end{array}$ & $\begin{array}{l}7.37 \mathrm{E}-1 \\
(2.60 \mathrm{E}+1)\end{array}$ & $\begin{array}{l}1.01 \mathrm{E}+0 \\
(3.56 \mathrm{E}+1)\end{array}$ \\
\hline & 97 & 4409 (73.5) & $5.90(19.37)$ & $2.47(8.11)$ & 12.79 & $\begin{array}{l}4.61 \mathrm{E}-2 \\
(4.96 \mathrm{E}-1)\end{array}$ & $\begin{array}{l}5.98 \mathrm{E}-2 \\
(6.43 \mathrm{E}-1)\end{array}$ & $\begin{array}{l}8.33 \mathrm{E}-1 \\
(2.94 \mathrm{E}+1)\end{array}$ & $\begin{array}{l}1.08 \mathrm{E}+0 \\
(3.81 \mathrm{E}+1)\end{array}$ \\
\hline
\end{tabular}




\section{2-year storm}

The 2-year storm produced little measurable overtopping. Because the water level was so much lower during this test series (+2.0 LWD), there was a significant increase in the amount of reflected waves. At the peak of the storm, roughly one of every ten waves was overtopping the structure, but these waves were significantly smaller than those seen during the 20-year storm. None of the waves that overtopped the structure during this event impacted the back of the catch basin. For this event the maximum overtopping rates recorded were $8.83 \mathrm{E}-4 \mathrm{cu} \mathrm{m} / \mathrm{sec}-\mathrm{m}(0.095 \mathrm{cu} \mathrm{ft} /$ $\mathrm{sec}-\mathrm{ft})$ for the three-stone row design and 8.69E-4 cu m/sec-m (0.094 cu $\mathrm{ft} / \mathrm{sec}-\mathrm{ft}$ ) for the two-stone row design. See Table 4 for wave information and overtopping rates for the 2-year storm.

\section{Overtopping prediction}

Overtopping data from the previously described tests were used to develop a predictive equation for overtopping rate. The application of the equation is limited to the very narrow range of test conditions summarized in this report. Based on both the two- and three-stone row designs, the two water levels, and two storm conditions, the equation best representing the overtopping for Montrose to Irving Section 1 was found to be:

$$
q=\sqrt{g H_{m 0}^{3}} \cdot \exp \left(-5.0 \frac{R_{c}}{H_{m 0}}\right)
$$

where

$$
\begin{aligned}
q= & \text { measured overtopping rate in the wave flume per unit length } \\
& \text { of structure } \\
g= & \text { acceleration due to gravity } \\
R_{c}= & \text { freeboard } \\
H_{m o}= & \text { incident nearshore spectral significant wave height. }
\end{aligned}
$$


Table 4. Wave properties and overtopping rates for 2-year storm.

\begin{tabular}{|c|c|c|c|c|c|c|c|c|c|}
\hline \multirow[b]{2}{*}{ Test } & \multirow{2}{*}{$\begin{array}{l}\text { Percent of } \\
\text { Target } H_{m 0}\end{array}$} & \multirow{2}{*}{$\begin{array}{l}\text { Duration } t \\
\sec (\min )\end{array}$} & \multirow{2}{*}{$\begin{array}{l}\text { Offshore Incident } \\
\text { Wave Height } \\
H_{m 0}, \mathrm{~m} \text { (ft) }\end{array}$} & \multirow{2}{*}{$\begin{array}{l}\text { Nearshore Incident } \\
\text { Wave Height } \\
H_{m 0}, \mathrm{~m} \text { (ft) }\end{array}$} & \multirow{2}{*}{$\begin{array}{l}\text { Peak Wave } \\
\text { Period } \\
T_{p}, \text { sec }\end{array}$} & \multicolumn{2}{|c|}{$\begin{array}{l}\text { Instantaneous Overtopping } \\
q, \text { cu } \mathrm{m} / \mathrm{sec}-\mathrm{m} \text { (cu ft/sec-ft) }\end{array}$} & \multicolumn{2}{|c|}{$\begin{array}{c}\text { Total Overtopping } \\
\mathrm{Q}, \mathrm{cu} \mathrm{m} / \mathrm{sec} \text { (cu ft/sec) }\end{array}$} \\
\hline & & & & & & 2 Stone & 3 Stone & 2 Stone & 3 Stone \\
\hline \multirow[t]{5}{*}{$\begin{array}{l}\text { First } \\
\text { run }\end{array}$} & 29 & 4409 (73.5) & $1.44(4.72)$ & $1.44(4.72)$ & 11.71 & $\begin{array}{l}0.00 E+0 \\
(0.00 E+0)\end{array}$ & $\begin{array}{l}0.00 \mathrm{E}+0 \\
(0.00 \mathrm{E}+0)\end{array}$ & $\begin{array}{l}0.00 E+0 \\
(0.00 E+0)\end{array}$ & $\begin{array}{l}0.00 \mathrm{E}+0 \\
(0.00 \mathrm{E}+0)\end{array}$ \\
\hline & 55 & 4409 (73.5) & $2.74(8.98)$ & $2.00(6.56)$ & 11.71 & $\begin{array}{l}1.91 \mathrm{E}-4 \\
(2.06 \mathrm{E}-3)\end{array}$ & $\begin{array}{l}1.98 \mathrm{E}-4 \\
(2.13 \mathrm{E}-3)\end{array}$ & $\begin{array}{l}3.45 \mathrm{E}-3 \\
(1.22 \mathrm{E}-1)\end{array}$ & $\begin{array}{l}3.57 \mathrm{E}-3 \\
(1.26 \mathrm{E}-1)\end{array}$ \\
\hline & 72 & 4409 (73.5) & 3.62 (11.89) & $1.99(6.54)$ & 11.71 & \begin{tabular}{|l|}
$2.07 \mathrm{E}-4$ \\
$(2.22 \mathrm{E}-3)$
\end{tabular} & $\begin{array}{l}1.82 \mathrm{E}-4 \\
(1.96 \mathrm{E}-3)\end{array}$ & $\begin{array}{l}3.73 \mathrm{E}-3 \\
(1.32 \mathrm{E}-1)\end{array}$ & \begin{tabular}{|l|}
$3.29 \mathrm{E}-3$ \\
$(1.16 \mathrm{E}-1)$
\end{tabular} \\
\hline & 86 & 4409 (73.5) & $4.30(14.09)$ & $1.96(6.42)$ & 11.71 & $\begin{array}{l}7.41 \mathrm{E}-4 \\
(7.98 \mathrm{E}-3)\end{array}$ & $\begin{array}{l}5.59 \mathrm{E}-4 \\
(6.02 \mathrm{E}-3)\end{array}$ & $\begin{array}{l}1.34 \mathrm{E}-2 \\
(4.73 \mathrm{E}-1)\end{array}$ & $\begin{array}{l}1.01 \mathrm{E}-2 \\
(3.57 \mathrm{E}-1)\end{array}$ \\
\hline & 100 & 4409 (73.5) & 4.99 (16.38) & $1.95(6.41)$ & 11.71 & $\begin{array}{l}1.13 \mathrm{E}-3 \\
(1.21 \mathrm{E}-2)\end{array}$ & $\begin{array}{l}1.07 \mathrm{E}-3 \\
(1.15 \mathrm{E}-2)\end{array}$ & $\begin{array}{l}2.03 \mathrm{E}-2 \\
(7.17 \mathrm{E}-1)\end{array}$ & $\begin{array}{l}1.94 \mathrm{E}-2 \\
(6.84 \mathrm{E}-1)\end{array}$ \\
\hline \multirow[t]{5}{*}{ Repeat } & 30 & 4409 (73.5) & $1.49(4.90)$ & $1.40(4.58)$ & 11.71 & $\begin{array}{l}0.00 \mathrm{E}+0 \\
(0.00 \mathrm{E}+0)\end{array}$ & $\begin{array}{l}0.00 E+0 \\
(0.00 E+0)\end{array}$ & $\begin{array}{l}0.00 \mathrm{E}+0 \\
(0.00 \mathrm{E}+0)\end{array}$ & $\begin{array}{l}0.00 \mathrm{E}+0 \\
(0.00 \mathrm{E}+0)\end{array}$ \\
\hline & 55 & 4409 (73.5) & $2.76(9.06)$ & $2.02(6.63)$ & 11.71 & $\begin{array}{l}3.18 \mathrm{E}-4 \\
(3.42 \mathrm{E}-3)\end{array}$ & $\begin{array}{l}2.41 \mathrm{E}-4 \\
(2.60 \mathrm{E}-3)\end{array}$ & $\begin{array}{l}5.74 \mathrm{E}-3 \\
(2.03 \mathrm{E}-1)\end{array}$ & $\begin{array}{l}4.36 \mathrm{E}-3 \\
(1.54 \mathrm{E}-1)\end{array}$ \\
\hline & 72 & 4409 (73.5) & 3.62 (11.89) & 2.02 (6.61) & 11.71 & $\begin{array}{l}2.45 \mathrm{E}-4 \\
(2.63 \mathrm{E}-3)\end{array}$ & $\begin{array}{l}1.70 \mathrm{E}-4 \\
(1.83 \mathrm{E}-3)\end{array}$ & $\begin{array}{l}4.42 \mathrm{E}-3 \\
(1.56 \mathrm{E}-1)\end{array}$ & $\begin{array}{l}3.07 \mathrm{E}-3 \\
(1.09 \mathrm{E}-1)\end{array}$ \\
\hline & 86 & 4409 (73.5) & $4.32(14.17)$ & $1.99(6.52)$ & 11.71 & $\begin{array}{l}8.37 \mathrm{E}-4 \\
(9.01 \mathrm{E}-3) \\
\end{array}$ & \begin{tabular}{|l|}
$6.16 \mathrm{E}-4$ \\
$(6.63 \mathrm{E}-3)$ \\
\end{tabular} & $\begin{array}{l}1.51 \mathrm{E}-2 \\
(5.34 \mathrm{E}-1) \\
\end{array}$ & $\begin{array}{l}1.11 \mathrm{E}-2 \\
(3.93 \mathrm{E}-1)\end{array}$ \\
\hline & 99 & 4409 (73.5) & $4.97(16.30)$ & 1.95 (6.39) & 11.71 & $\begin{array}{l}6.09 \mathrm{E}-4 \\
(6.56 \mathrm{E}-3)\end{array}$ & $\begin{array}{l}7.00 \mathrm{E}-4 \\
(7.53 \mathrm{E}-3)\end{array}$ & $\begin{array}{l}1.10 \mathrm{E}-2 \\
(3.89 \mathrm{E}-1)\end{array}$ & $\begin{array}{l}1.26 \mathrm{E}-2 \\
(4.46 \mathrm{E}-1)\end{array}$ \\
\hline
\end{tabular}


Freeboard is defined as the vertical distance from the still water level to the crest of the highest stone. The equation was adapted from the Coastal Engineering Manual (Headquarters, U.S. Army Corps of Engineers 2002) equation for short-crested waves (Equation VI-5-25). The form of the equation and the relationships of variables were not changed from the original form; only the coefficients were changed. Figure 20 illustrates overtopping rates predicted by Equation 1 versus the measured overtopping rates for all test cases.

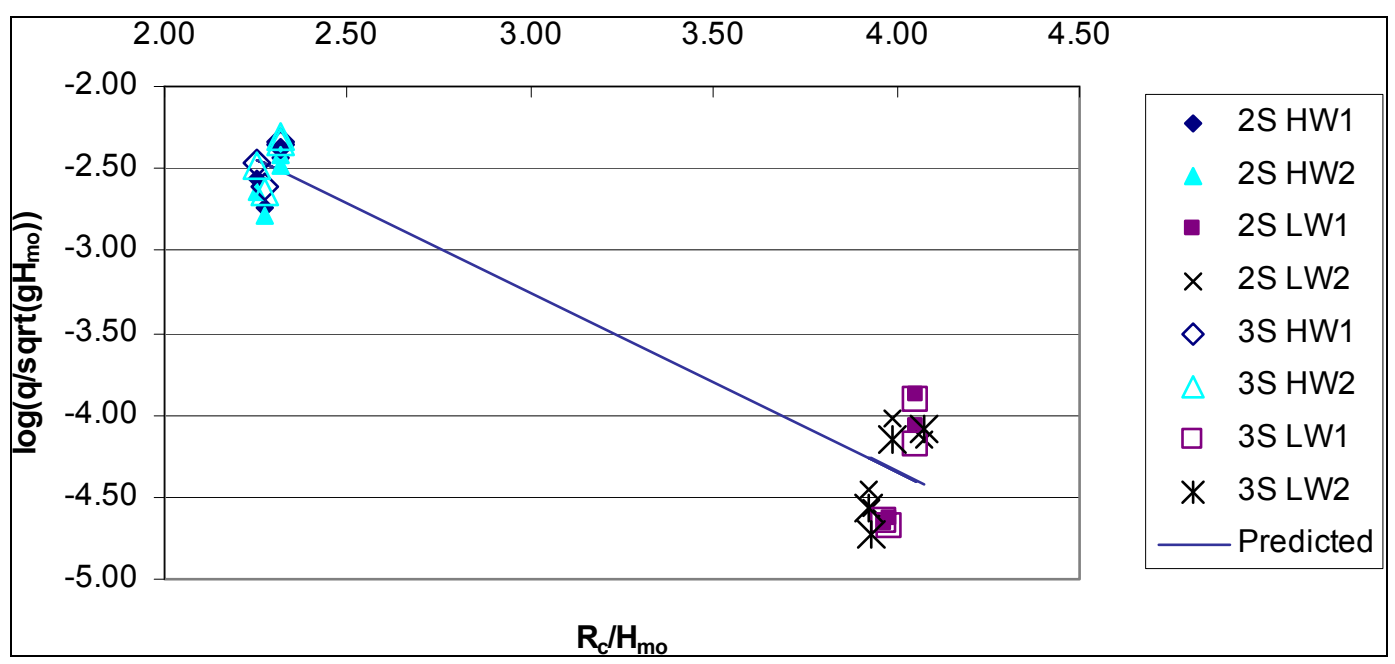

Figure 20. Predicted and measured overtopping (2S denotes two-stone row design, $3 \mathrm{~S}$ denotes three-stone row design; HW represents $+1.71 \mathrm{~m}(+5.6 \mathrm{ft})$ LWD lake level tested with the 20-year storm condition, and LW represents $+0.61 \mathrm{~m}(+2.0 \mathrm{ft})$ LWD lake level tested with the 2-year storm condition; 1 indicates initial run and 2 indicates repeat run).

\section{Overtopping comparison}

As previously mentioned, in an earlier investigation, equations were developed to estimate the overtopping volume for stepped revetments along the Chicago shoreline (Ward 2003). A comparison of Equation 1 and Ward's equation using the geometry of the Montrose to Irving reach revetment is shown in Figures 21 and 22 for the 20-year and 2-year storm events, respectively. The measured overtopping rate is the average of both the first run and the repeat of both the two- and three-stone row sides. Table 5 gives the geometric parameters for the cross section that were used to calculate the overtopping as outlined by Ward (2003, pages 44-45). 


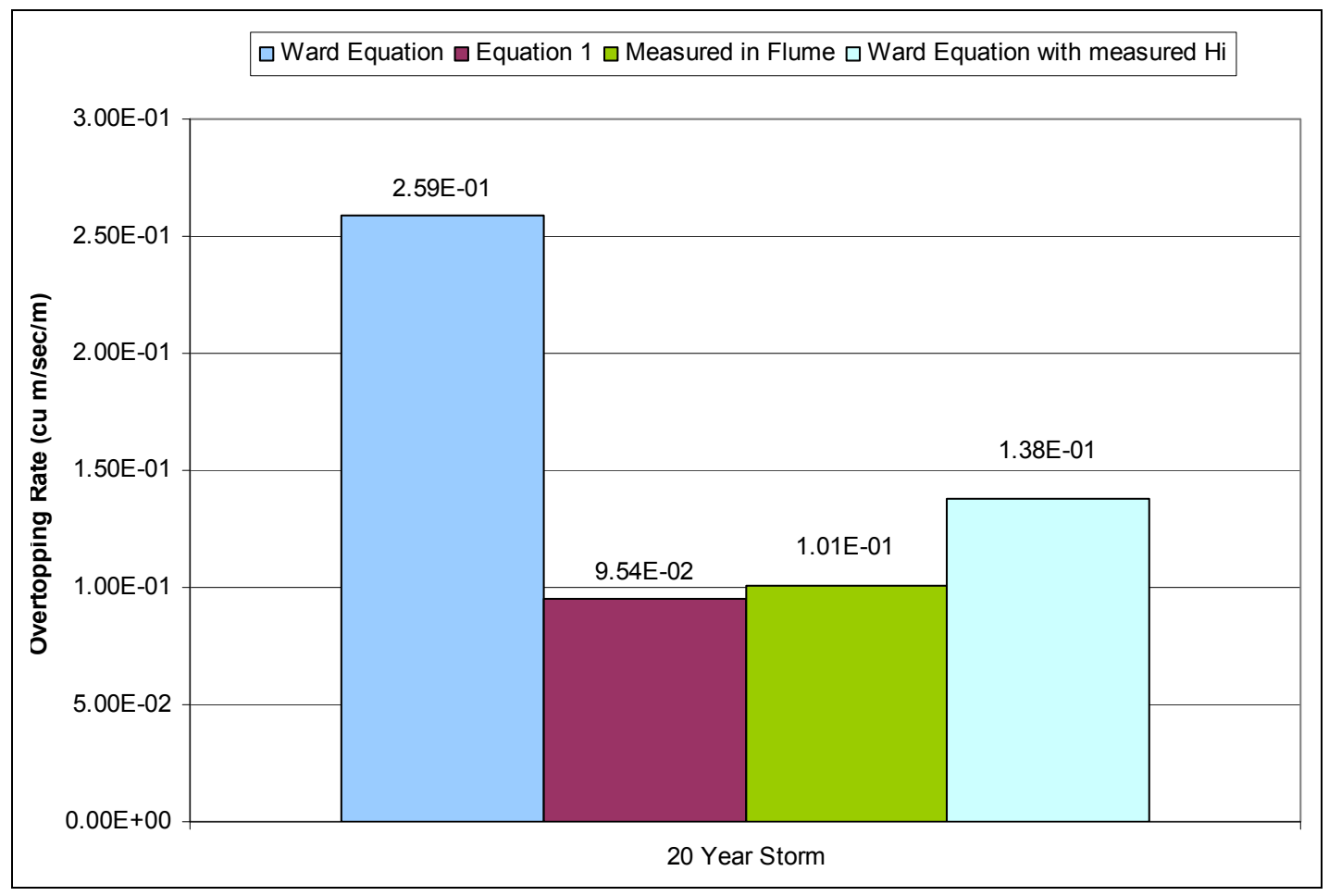

Figure 21. Comparison of results from Equation 1, measured overtopping recorded during testing, and Ward's equation for revetment geometry during 20-year storm event.

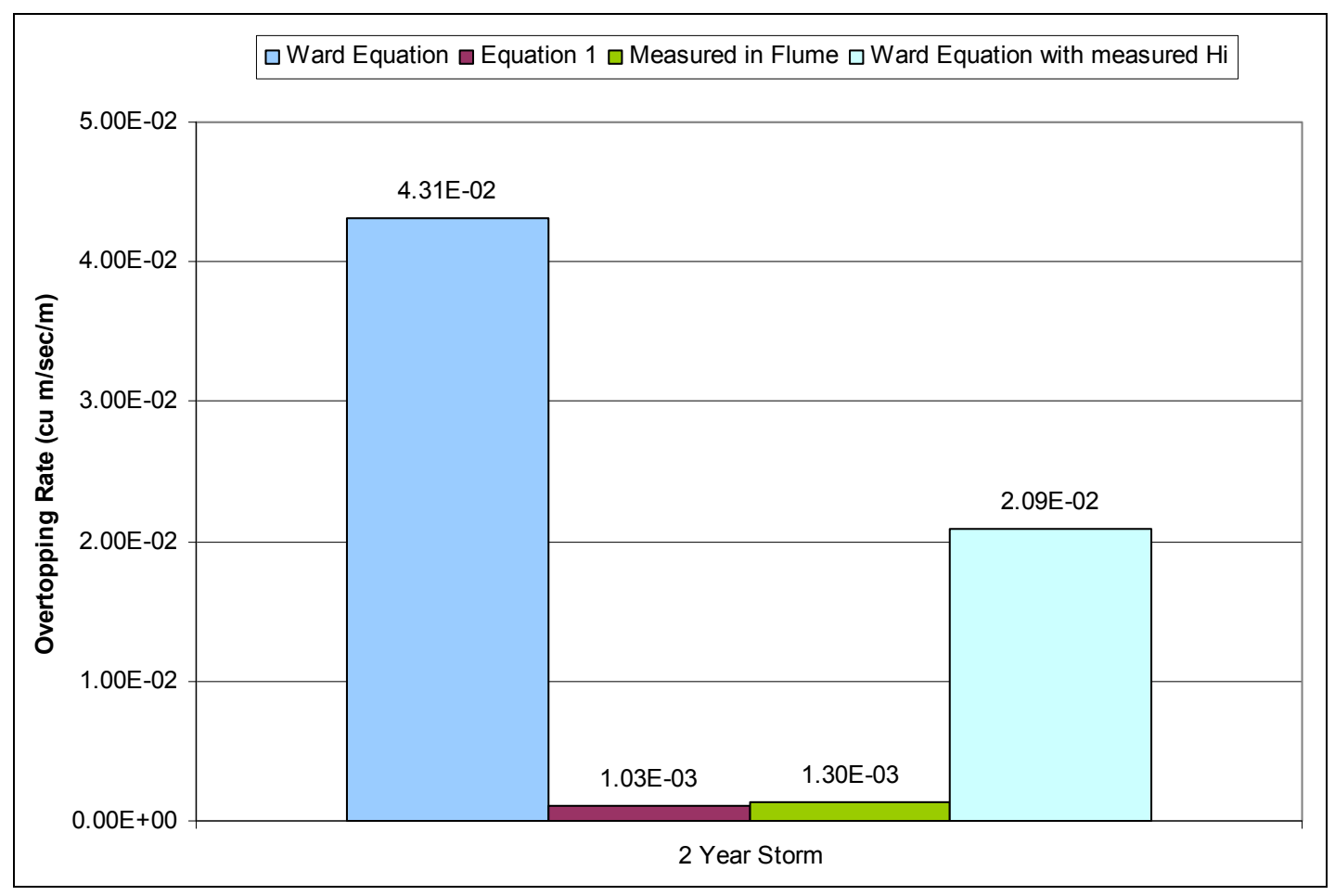

Figure 22. Comparison of results from Equation 1, measured overtopping recorded during testing, and Ward's equation for revetment geometry during 2 -year storm event. 
Calculations were originally made in non-metric units, and the geometric parameters of the structure did not change between the 20-year and 2-year storm events. It can be seen that the overtopping rate predicted by Ward's equation is significantly higher than is predicted by Equation 1 and the measured overtopping. This may be partially due to the differences in measurement and
Table 5. Geometric parameters for revetment cross section used for calculation in Ward's equation with elevations referred to Lake Michigan LWD.

\begin{tabular}{|l|l|}
\hline$h_{\text {prom, }} \mathrm{m}(\mathrm{ft})$ & $1.5(5.0)$ \\
\hline$h_{\text {crest, }} \mathrm{m}(\mathrm{ft})$ & $4.6(15.0)$ \\
\hline$h_{\text {toe }}, \mathrm{m}(\mathrm{ft})$ & $-4.0(-13.0)$ \\
\hline Slope $\theta$ & 0.005 \\
\hline 20-year SWL, m (ft) & $1.7(5.6)$ \\
\hline 2-year SWL, m (ft) & $0.61(2.0)$ \\
\hline
\end{tabular}
analysis of waves between the two experiments and, to a lesser extent, the details of wave-structure interaction and wave reflection. Ward used an analytically estimated wave height based on Goda's semi-empirical method (Goda 1985) and an equivalent deep-water wave height. The estimated shallow-water significant wave height using this method was $3.72 \mathrm{~m}(12.2 \mathrm{ft})$. This yields a ration $H_{m o} /$ depth $=0.67$ for the 20 -yr storm, which is very high for the flat offshore bathymetry. The measured wave height of $2.47 \mathrm{~m}(8.11 \mathrm{ft})$ was much more reasonable. Using $H_{m o}=2.47 \mathrm{~m}$ $(8.1 \mathrm{ft})$ in Ward's equation yields a $q=0.14 \mathrm{cu} \mathrm{m} / \mathrm{sec}-\mathrm{m}(0.57 \mathrm{cu} \mathrm{ft} / \mathrm{sec}-\mathrm{ft})$, which is very close to the overtopping calculated by Equation 1 for the conditions. This also explains the large discrepancy in the 2-yr storm results. Because overtopping is a threshold event and the 2-yr storm is near the threshold of overtopping, small differences in wave height will produce large differences in predicted overtopping. 


\section{Conclusions and Recommendations}

A physical model study was conducted to determine overtopping rates and observe stone stability for a composite limestone and concrete stepped revetment along the Montrose to Irving reach of the Chicago shoreline. The design incorporates reuse of the existing limestone blocks as requested for evaluation by IHPA, while attempting to provide adequate shoreline protection for the Montrose to Irving reach.

Of the existing cut limestone blocks that are to be reused in the design, it is recommended that stones no smaller than $36-45 \mathrm{kN}$ (4-5 tons) be used in construction of the seaward steps and that stones no smaller than 27-36 kN (3-4 tons) be used anywhere in the structure. Placing stones as close as possible to one another is required to brace the stones as much as possible. Small voids between placed stones can be filled with underlayer or fill material, but it will eventually be washed out from the structure. Cut stones should be embedded at least 25 percent of their total height into bedding material to improve stability.

Based on observations of the simulated 20-year storm, during large storm events, stones can be expected to shift slightly because of the impact of large waves. Damage to the model structure was limited, and no significant stone movement was noted (i.e., no stones were completely lost from the structure). Marine mattresses were very effective at providing extra stability to the crest stones and, in turn, the entire structure. By preventing the erosion of fill material landward of the crest, the structure performance was greatly improved. It is recommended that marine mattresses or a comparable type of backshore erosion protection be incorporated as part of the revetment construction.

A predictive overtopping equation was fit to data collected during testing for both the two- and three-stone row designs. The estimated overtopping using this equation was compared to the actual overtopping measured in the study and the overtopping predicted using Ward's equation (Ward 2003). The application of the equation for the estimation of overtopping developed during this study is limited to the conditions discussed in this report. 


\section{References}

Goda, Y. 1985. Random seas and design of maritime structures. Tokyo, Japan: University of Tokyo Press.

Hasselmann, K., T. P. Barnett, E. Bouws, H. Carlson, D. E. Cartwright, K. Enke, J. Ewing, H. Gienapp, D. E. Hasselmann, P. Krusemann, A. Meerburg, P. Muller, D. J. Olbers, K. Richter, W. Sell, and H. Walden. 1973. Measurements of wind-wave growth and swell decay during the Joint Sea Wave Project (JONSWAP). Hamburg, Germany: Deutshes Hydrographisches Institut.

Headquarters, U.S. Army Corps of Engineers. 2002. Coastal Engineering Manual. Engineering Manual EM 1110-2-1100. Washington, DC: U.S. Army Corps of Engineers (in six volumes).

Hughes, S. A. 2006. Uses for marine mattresses in coastal engineering. Coastal and Hydraulics Laboratory Technical Notes Collection. ERDC/CHL CHETN-III-72. Vicksburg, MS: U.S. Army Engineer Research and Development Center.

Krecic, M.R., and O.J. Sayao. 2003. Wave overtopping on Chicago shoreline revetment. In Coastal Structures 'o3, ed J. Melby, 543-554. Reston, VA: American Society of Civil Engineers.

Ward, D. L. 2003. Overtopping studies of a stepped revetment for city of Chicago, Illinois. ERDC/CHL TR-03-14. Vicksburg, MS: U.S. Army Engineer Research and Development Center. 


\section{REPORT DOCUMENTATION PAGE}

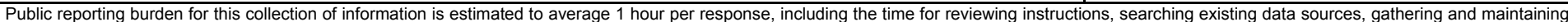

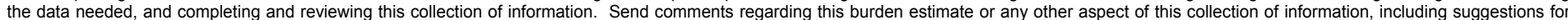

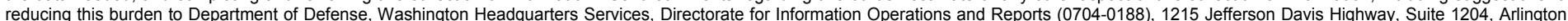

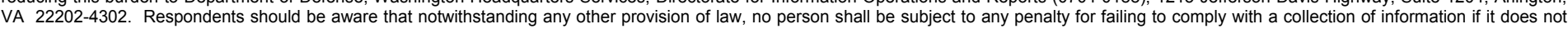
display a currently valid OMB control number. PLEASE DO NOT RETURN YOUR FORM TO THE ABOVE ADDRESS.

\begin{tabular}{l|l}
$\begin{array}{l}\text { 1. REPORT DATE (DD-MM-YYYY) } \\
\text { February } 2008\end{array}$ & $\begin{array}{c}\text { 2. REPORT TYPE } \\
\text { Final report }\end{array}$ \\
\hline
\end{tabular}

\section{TITLE AND SUBTITLE}

Stability and Overtopping Study of Montrose to Irving Reach of Chicago, IL, Shoreline Revetment

3. DATES COVERED (From - To)

5a. CONTRACT NUMBER

5b. GRANT NUMBER

5c. PROGRAM ELEMENT NUMBER

5d. PROJECT NUMBER

5e. TASK NUMBER

5f. WORK UNIT NUMBER

8. PERFORMING ORGANIZATION REPORT NUMBER

ERDC/CHL TR-08-1

U.S. Army Engineer Research and Development Center

Coastal and Hydraulics Laboratory

3909 Halls Ferry Road

Vicksburg, MS 39180-6199

9. SPONSORING / MONITORING AGENCY NAME(S) AND ADDRESS(ES)

10. SPONSOR/MONITOR'S ACRONYM(S)

Headquarters, U.S. Army Corps of Engineers

Washington, DC 20314-1000

11. SPONSOR/MONITOR'S REPORT NUMBER(S)

\section{DISTRIBUTION / AVAILABILITY STATEMENT}

Approved for public release; distribution is unlimited.

\section{SUPPLEMENTARY NOTES}

\section{ABSTRACT}

The stepped stone revetment along the City of Chicago's Lake Michigan shoreline, directly south of Montrose Harbor, is failing and in need of repair. The Illinois Historical Preservation Agency (IHPA) requested that the cut limestone blocks from the original structure be evaluated for use in the new revetment design. A physical model study was conducted at the U.S. Army Engineer Research and Development Center's Coastal and Hydraulics Laboratory to assist in the design of the composite structure. During the experiments, overtopping rates were measured and stone stability was noted. Construction-related issues, overtopping, and the sizing and stability of cut limestone blocks were of major interest during the study.

$\begin{array}{ll}\text { 15. SUBJECT TERMS } & \text { Lake Michigan } \\ \text { Chicago, IL } & \text { Montrose, IL } \\ \text { Irving, IL } & \text { Overtopping }\end{array}$

16. SECURITY CLASSIFICATION OF:

a. REPORT

UNCLASSIFIED

b. ABSTRACT
UNCLASSIFIED

c. THIS PAGE

UNCLASSIFIED

\begin{tabular}{|l|l|l|}
\multicolumn{4}{c}{$\begin{array}{l}\text { Physical model } \\
\text { Revetment } \\
\text { Stepped }\end{array}$} \\
\hline $\begin{array}{ll}\text { 17. LIMITATION } \\
\text { OF ABSTRACT }\end{array}$ & $\begin{array}{l}\text { 18. NUMBER } \\
\text { OF PAGES }\end{array}$ & $\begin{array}{l}\text { 19a. NAME OF RESPONSIBLE } \\
\text { PERSON }\end{array}$ \\
\cline { 3 - 4 } & 35 & $\begin{array}{l}\text { 19b. TELEPHONE NUMBER (include } \\
\text { area code) }\end{array}$ \\
& 35 & \\
\hline
\end{tabular}

